\title{
Animal models to explore the effects of glucocorticoids on skeletal growth and structure
}

\author{
Claire L Wood', Ondrej Soucek2,3, Sze C Wong4, Farasat Zaman³, Colin Farquharson', Lars Savendahl3 and \\ S Faisal Ahmed 4 \\ 'Division of Developmental Biology, Roslin Institute, University of Edinburgh, Edinburgh, UK \\ 2Department of Paediatrics, 2nd Faculty of Medicine, Charles University in Prague and Motol University Hospital, Prague, Czech Republic \\ 3Department of Women's and Children's Health, Karolinska Institutet and Pediatric Endocrinology Unit, Karolinska University Hospital, \\ Stockholm, Sweden \\ ${ }^{4}$ Developmental Endocrinology Research Group, School of Medicine, University of Glasgow, Glasgow, UK \\ Correspondence should be addressed to S F Ahmed: Faisal.ahmed@glasgow.ac.uk
}

\section{Abstract}

Glucocorticoids (GCs) are effective for the treatment of many chronic conditions, but their use is associated with frequent and wide-ranging adverse effects including osteoporosis and growth retardation. The mechanisms that underlie the undesirable effects of GCs on skeletal development are unclear, and there is no proven effective treatment to combat them. An in vivo model that investigates the development and progression of GC-induced changes in bone is, therefore, important and a wellcharacterized pre-clinical model is vital for the evaluation of new interventions. Currently, there is no established animal model to investigate GC effects on skeletal development and there are pros and cons to consider with the different protocols used to induce osteoporosis and growth retardation. This review will summarize the literature and highlight the models and techniques employed in experimental studies to date.

\author{
Key Words \\ - glucocorticoids \\ - growth \\ - mouse \\ - murine \\ - osteoporosis \\ - skeletal development
}

Journal of Endocrinology (2018) 236, R69-R91

\section{Introduction and background}

It is estimated that, at any one time, over 250,000 people are exposed to systemic glucocorticoids (GCs); approximately $10 \%$ of children will require GCs at some stage during their childhood (Mushtaq \& Ahmed 2002) and $5 \%$ of the population aged 80 years or over have used GCs in the past (Kanis et al. 2004). Long-term GCs are effective in many conditions, such as inflammatory bowel disease (Pappa et al. 2011), chronic renal disorders (Olgaard et al. 1992), lung conditions, haematological malignancies (El-Hajj Fuleihan et al. 2012) and connective tissue disease, and in some, such as Duchenne muscular dystrophy (DMD) (Matthews et al. 2016), they are the mainstay of long-term treatment. Unfortunately, GCs are associated with frequent and wide-ranging side effects, many of which are dose related and associated with considerable morbidity. Of these, two of the potentially most serious and challenging to manage are glucocorticoid-induced osteoporosis (GIO) and growth retardation. Osteoporosis is characterized by a reduction in bone mass and loss of bone microarchitecture, leading to impaired bone strength and increased fracture risk (Reinwald \& Burr 2008). GIO is the most prevalent type of secondary osteoporosis and accounts for about $25 \%$ of cases (Eastell et al. 1998). It is associated with considerable morbidity and mortality; a reduction in bone mineral density (BMD) of up to $40 \%$ can occur with GC therapy, and it is estimated that up to half of those on long-term GC therapy will experience fractures (Reid 1997). In those with DMD, 75\% are predicted to have a vertebral fracture after 8 years of GC therapy (Bothwell et al. 2003), and this 
event is often followed by loss of ambulation (McDonald et al. 2002). The General Practice Research Database has shown that daily prednisolone doses of as little as $2.5 \mathrm{mg}$ can cause an increased risk of fracture (Van Staa et al. 2000). A recent meta-analysis also showed that there is only weak evidence for the use of common osteoporosis drugs in the prevention of fractures (Amiche et al. 2016), suggesting that there is great need for pre-clinical work to inform the development of new therapies.

As healthy children have high rates of bone growth, their skeleton is particularly vulnerable to the adverse effects of GCs on bone formation. GC-induced growth retardation was first described 60 years ago after an equivalent cortisone dose of only $1.5 \mathrm{mg} / \mathrm{kg} / \mathrm{day}$ (Blodgett et al. 1956) and can be considerable; by 15 years of age, boys with DMD who are treated with deflazacort are $21 \mathrm{~cm}$ shorter on average than untreated boys (Biggar et al. 2006). GC-induced growth retardation can also occur following GC exposure by several alternative routes including inhaled GC in asthma (Allen et al. 1994) and intraarticular GC injections in juvenile arthritis (Umlawska \& Prusek-Dudkiewicz 2010). GC-induced growth retardation is dose dependent and alternate-day or weekend dosing is associated with less growth retardation (Escolar et al. 2011, Ricotti et al. 2013). In children, although compensatory catch-up growth may occur after cessation of GC therapy (Crofton et al. 1998), prolonged exposure may reduce the potential for catch-up (Simon et al. 2002).

\section{Skeletal development}

The foetal skeleton develops in two distinct ways; intramembranous ossification occurs within flat bones including the skull and facial bones, whereas endochondral ossification accounts for the linear development of the long bones such as the femur and tibia. Appositional growth also occurs, whereby bone lining the medullary cavity is reabsorbed and new bone tissue is laid down beneath the periosteum, thus increasing bone diameter. This can still occur even after longitudinal growth ceases. In this review, we shall focus on endochondral ossification, which is driven by the actions of the chondrocytes within the epiphyseal growth plate and is the process responsible for bone formation and longitudinal growth of the majority of the skeleton. During the initial, patterning phase of skeletal development, mesenchymal cells condense into tissue elements at specific sites that form the structure of future bones (Karsenty \& Wagner 2002). By 5-week gestation in humans, these pre-cartilaginous anlagen reflect the shape, size, position and number of skeletal elements that will be present in the mature skeleton (Javaid \& Cooper 2002). Following this, differentiation to either chondrocytes or osteoblasts occurs within the condensations. Chondrocytes within each element organize into growth plates and move through their associated orderly pattern of resting, proliferative and hypertrophic phases (Mackie et al. 2011). Once they reach the hypertrophic phase, chondrocytes promote invasion of blood vessels and the production of an extracellular matrix (ECM) that is rich in type II collagen, aggrecan, cytokines and vascular growth factors, which facilitates vascular invasion and gradual mineralization of the ECM surrounding the hypertrophic chondrocyte. The cartilaginous ECM is gradually replaced by a bony ECM (rich in type I collagen), when apoptosis of the hypertrophic chondrocytes occurs and osteoblasts invade the cartilaginous scaffold. As osteoblasts lay down new bone, to form the periosteum, the primary ossification centre expands towards the ends of the cartilage model. In long bones, a secondary ossification centre subsequently forms at each end of the bone, leaving a cartilaginous growth plate in between the two ossification centres. Growth is orchestrated at the growth plates but at puberty, bony bridges form between the ossification centres, resulting in the cessation of growth due to the fusion of the growth plate and its replacement by bone. After birth, a continuing cycle of modelling (or remodelling in adults when it occurs without a change in bone shape) occurs, and there is a fine balance between bone formation and bone resorption to ensure that bone can sense and adapt to alterations in functional, metabolic and mechanical demands.

\section{GCs and their mechanisms}

\section{GC-induced osteoporosis}

The aetiology of GC-induced osteoporosis is complex and a detailed review of the underlying mechanisms as recently reported (Henneicke et al. 2014) is beyond the scope of the current review. Instead, we will summarise the key mechanisms and the differing effects of GCs in osteoblasts, osteoclasts and osteocytes. There are two distinct phases of GC-induced bone loss, resulting from the suppressive effects of GCs on both osteoblastogenesis and osteoclastogenesis. The initial acute period of increased bone resorption is followed by a more indolent phase of bone loss caused by a reduction in bone formation 


\begin{tabular}{l|l|l||c|c|}
$\begin{array}{l}\text { Journal of } \\
\text { Endocrinology }\end{array}$ & C L Wood et al. & $\begin{array}{l}\text { Animal models for GC effects on } \\
\text { skeleton }\end{array}$ & $\mathbf{2 3 6 : 1}$ & $\mathbf{R 7 1}$ \\
\hline
\end{tabular}

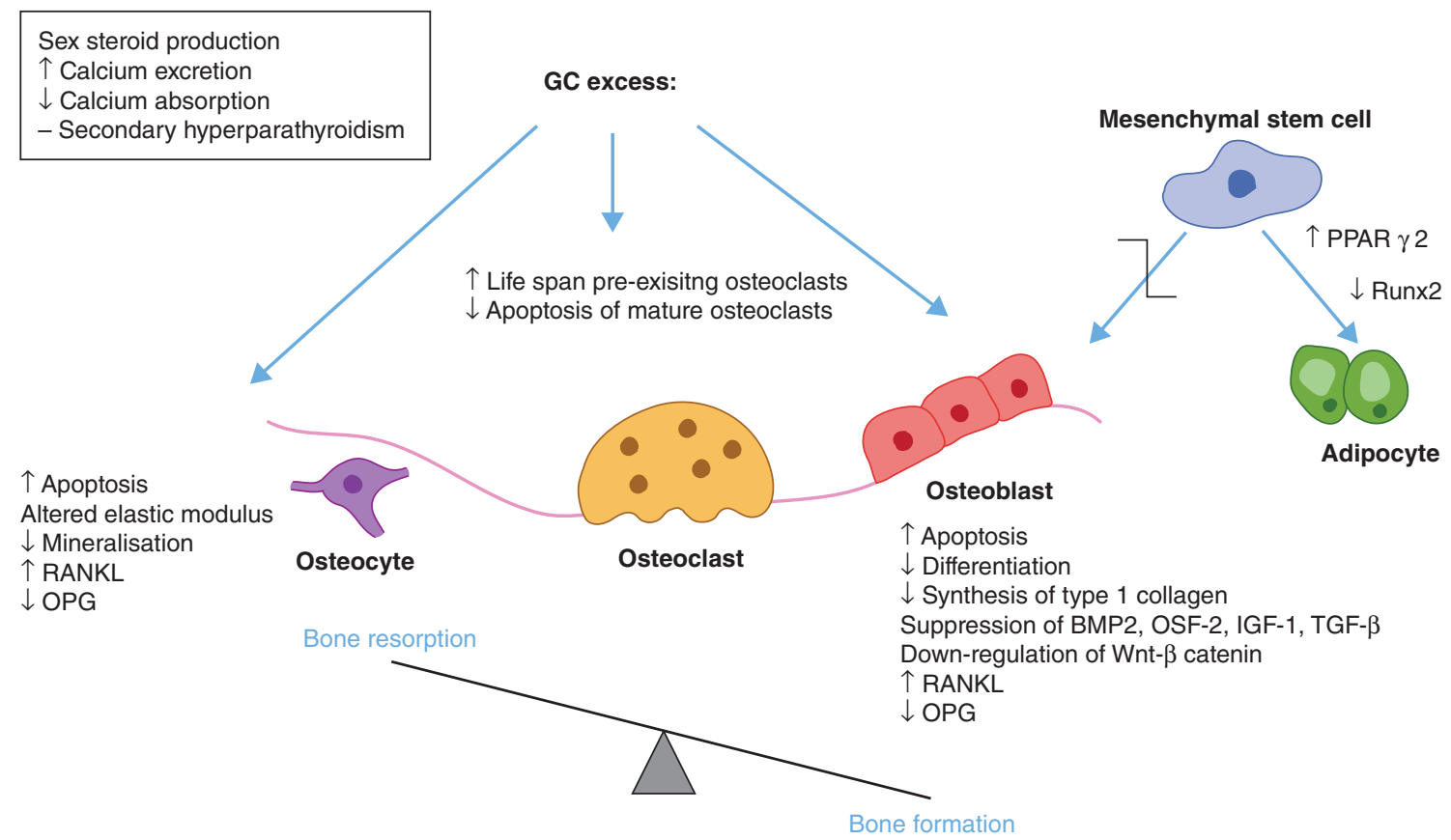

Figure 1

Systemic consequences of exogenous glucocorticoids and effects on different bone cells and adipocytes. BMP2, bone morphogenetic protein 2; IGF-1, insulin-like growth factor-1; Legend-RANKL, receptor activator of nuclear factor kappa-B ligand; OPG, osteoprotegrin; OSF-2, osteoblast-specific factor-2; TGF- $\beta$, transforming growth factor beta.

(Canalis et al. 2004). Indirect effects of GCs on the skeleton such as decreased calcium absorption, increased renal calcium clearance, reduced growth hormone (GH) secretion and suppression of sex steroid metabolism were previously thought to play a fundamental role, but the main mechanisms underlying GIO are now known to result from the direct effect of GCs on the resident bone cells, see Fig. 1.

Glucocorticoids and mineralocorticoids act through corticosteroid receptors - the mineralocorticoid receptor (MR) and the glucocorticoid receptor (GR). These receptors have often been referred to as Type 1 and Type 2 corticosteroid receptors, respectively (Eberwine 1999, Stewart 2007). The GR is expressed in many bone cells, including osteoblasts, osteoclasts and osteocytes (Bouvard et al. 2009) and also in chondrocytes within the growth plate. Once GCs bind to the GR in the cytoplasm, the GR translocates to the nucleus, where it acts as a transcription factor and modifies gene expression, via the GC-response element, either by causing transactivation or transrepression. Transactivation accounts for most of the GC-associated adverse effects and in vitro and murine studies demonstrate that selective GR modulators can alter the extent of these adverse effects (Owen et al. 2007, Thiele et al. 2012). However, studies using transgenic mice with a GR gene mutation that prevents dimerization and therefore transactivation still have reduced bone formation. This suggests that transrepression is probably also at least partly responsible (Rauch et al. 2010). Polymorphism of the GR gene is associated with varying susceptibility to GCs (Huizenga et al. 1998), which may in part explain the heterogeneity in GC-associated fracture rates in humans.

MicroRNAs (miRNAs) are endogenous RNAs made up of 18-25 nucleotides that interact with messenger RNA to change protein expression. Recent work has shown that several miRNAs have differential expression in GC-treated bone. For example, a reduction in miRNA-29a expression, which interacts with Wnt signalling components and Dkk-1 during osteoblast differentiation was associated with GC-associated bone loss. Gain of miRNA-29a function by a miRNA-29a precursor (Wang et al. 2013) attenuated the deleterious effects of GC treatment on bone mass, microarchitecture and biomechanical strength.

\section{Effects of GC on osteoblasts}

The chronic bone loss in GIO predominantly results from the ability of GCs to decrease both the number and functionality of osteoblasts. Osteoblasts and adipocytes are both derived from mesenchymal stem cells. By changing the fate of osteoprogenitor cells, GCs effectively reduce the pool of cells that can become mature, differentiated 
osteoblasts and bone marrow stromal cells are instead directed along the adipogenesis pathway. This has been shown to occur via the transactivation of CCAAT/ enhancer binding protein in murine stromal cells (Pereira et al. 2002), which increases expression of peroxisome proliferator-activated receptor gamma 2 (PPAR $\gamma 2$ ) and suppresses the expression of Runx2 (Canalis et al. 2004, 2007). GCs may, therefore, increase bone marrow adipose tissue at the expense of mature osteoblasts and cancellous bone (Weinstein \& Manolagas 2000). Outside of bone, GCs also promote preadipocycte conversion to mature adipocytes and thus cause hyperplasia of adipose tissue. A 2-fold increase in cancellous adipocyte area in GC-treated mice compared to placebo has been reported, alongside a significant increase in adipocyte production in bone marrow cultures (Weinstein \& Manolagas 2000). The exact mechanism(s) by which the reduction in osteoblastogenesis occurs is unclear; however, it is known that GCs cause suppression of bone anabolic factors such as bone morphogenetic proteins (Pereira et al. 2002), osteoblast-specific factor 2 (OSF-2) and insulin-like growth factor 1 (IGF-1) (Jones \& Clemmons $1995)$ and TGF- $\beta$ that activates osteoblastic transcription factors such as Runx 2 and $\beta$-catenin. In cultured human osteoblasts, exogenous GC administration also results in the suppression of the canonical Wnt- $\beta$-catenin signalling pathway, which prevents osteoblast apoptosis and encourages progression through the osteoblast cell cycle and thus proliferation (Ohnaka et al. 2005). Furthermore, murine GC exposure has been shown to upregulate sclerostin gene expression, which antagonises Wnt stimulation of osteoblast differentiation (Yao et al. 2016). Using a transgenic mouse line, GCs have also been shown to suppress interleukin 11 expression, which further inhibits osteoblast differentiation (Rauch et al. 2010). In addition to inhibiting osteoblast differentiation, GCs also prevent bone matrix synthesis by inhibiting osteoblast-driven synthesis of type I collagen, which forms most of the ECM (Canalis 2005) and osteocalcin. GC administration to mice has also been shown to induce osteoblast apoptosis and suppress terminal differentiation (Weinstein et al. 1998).

\section{Effects of GC on osteoclasts and osteocytes}

Osteoclasts are derived from haematopoetic stem cells and resorb bone by creating an acidic environment and producing collagen-degrading enzymes. GCs exert an early direct effect on osteoclasts by increasing both their number and activity, with a corresponding increase in bone resorption, seen after only 7 days
(C) 2018 Society for Endocrinology Published by Bioscientifica Ltd.
Printed in Great Britain of GC treatment in mice (Jia et al. 2006). This overall increase in osteoclast number occurs despite a reduction in osteoclast production in the bone marrow, suggesting that GC treatment increases the lifespan of preexisting osteoclasts. However, the longer term role of the osteoclast in glucocorticoid-induced osteoporosis remains controversial; despite an initial increase in bone resorption, prolonged GC excess appears to suppress osteoclast number and function. For example, after 4 weeks of prednisolone treatment in mice, bone resorption fell to or below normal levels (Weinstein et al. 1998). GCs also directly block the induction of cytoskeletal changes in the osteoclast required for the resorptive capabilities of the cell (Kim et al. 2007). There is also evidence that GCs suppress the proliferation of osteoclast precursors (Kim et al. 2006) However, GC also cause an increase in receptor activator of nuclear factor kappa beta ligand (RANKL) (Hofbauer et al. 2009), which is produced by both osteoblasts and osteocytes (Nakashima et al. 2011, Xiong et al. 2011) and downregulation of osteoprotegrin (OPG), which is a decoy receptor for RANKL. This skews the ratio of RANKL: OPG towards osteoclastogenesis. Overall, the long-term effect of exogenous GCs on osteoclastogenesis still requires clarification, but it appears that the osteoblast is the main target of exogenous GCs.

Osteocytes are terminally differentiated osteoblasts that play an important role in the repair of bone microdamage. GCs alter the osteocyte-canalicular network by changing the elastic modulus surrounding the lacunae of osteocytes and cause reduced mineralisation (Lane et al. 2006). Autophagy may be responsible for these observed localised osteocyte perilacunar changes, occurring as a self-protection mechanism during GC treatment (Xia et al. 2010). High-dose GC therapy in several animal and human models has also been shown to induce osteocyte apoptosis (Zalavras et al. 2003).

\section{GC-induced growth retardation}

The growth-suppressing effects of GCs are multifactorial and result from both systemic and local actions on all types of bone cell. The GH/IGF-1 axis is the main determinant of postnatal longitudinal growth, and GH and IGF-1 have interdependent roles in growth regulation. The rate of longitudinal bone growth is principally controlled through the regulation of chondrocyte proliferation, differentiation and hypertrophy at the growth plate (Wong et al. 2016). GH promotes chondrocyte differentiation, the secretion of IGF-1 by liver cells and the amplification 
of local IGF-1 synthesis by chondrocytes, which induces clonal expansion of chondrocyte columns within the growth plate (Zezulak \& Green 1986).

GCs also affect the expression of various components of the GH/IGF-1 axis (Price et al. 1992, Jux et al. 1998, Klaus et al. 2000, Smink et al. 2002). Seven days of dexamethasone treatment in prepubertal mice reduced gene expression of IGF-1 throughout chondrocytes in all phases within the growth plate (Smink et al. 2003a) as well as causing a significant increase in the number of apoptotic cells within the hypertrophic zone. Different mechanisms of GC-induced apoptosis have been proposed such as activation of caspase 3 and suppression of Bcl-2 (Chrysis et al. 2003, Espina et al. 2008). GCs block the activation of GH and IGF-1 receptors in chondrocytes as well as reducing IGF-1 and GH receptor expression by chondrocytes (Wong et al. 2016). Glucocorticoids also impair IGF-1 signalling, mainly via the phosphoinositide 3-kinase pathway within the growth plate. Furthermore, GCs suppress prostaglandin E2 synthesis (Harada et al. 1995) as well as vascular endothelial growth factor expression in chondrocytes, thus preventing blood vessel invasion of the ossification centre, which is crucial for degradation of the ECM and subsequent ossification and growth (Smink et al. 2003a). The intrinsic effect of GC on the mouse growth plate was evident when a local dexamethasone infusion significantly reduced tibial growth compared to the contralateral limb (Baron et al. 1992). GCs also act systemically to inhibit the pulsatile secretion of $\mathrm{GH}$ from the anterior pituitary gland by increasing somatostatin tone (Mazziotti \& Giustina 2013).

\section{Animal models of GIO- and GC-induced growth retardation}

It is essential to utilise animal models that show similar pathology to the human disease process that is under scrutiny, in order to effectively carry out pre-clinical studies and test novel compounds. GCs may lead to some localized changes in bone strength that are similar to other causes of osteoporosis, but they also display some unique effects which explains why GC exposure is associated with a higher risk of fracture at equivalent BMD and hence reinforcing the need for an appropriate animal model to specifically investigate GIO (Lane 2005, Xia et al. 2010). In addition, the search continues to find selective GR agonists that possess the anti-inflammatory benefits of traditional GCs without the associated adverse effects (Sundahl et al. 2015). Suitable pre-clinical models are also vital to this process.
It remains a challenge, however, to find an appropriate animal model for pre-clinical studies of skeletal development as there is no single animal model that exactly mimics the human pathology. Whilst larger animals such as primates and dogs may have the most similar reproductive, anatomical and physiological characteristics, there are ethical issues to consider as well as difficulties with their maintenance and costs (Reinwald \& Burr 2008). Sheep, rabbits, and pigs have also been developed as large animal models of GIO in previous studies (Scholz-Ahrens et al. 2007, Baofeng et al. 2010, Ding et al. 2010) but these too have limitations. The following section will discuss the various animal models used to investigate both GIO and GC-induced growth retardation.

\section{Animal species used for GC-induced osteoporosis models}

Different animal species have been used to explore the effect of GCs on the development of osteoporosis and to search for substances that prevent the observed deleterious effects. The inquiry performed on PubMed, with 'osteoporosis', 'glucocorticoids' and 'animal name' used as MeSH terms, retrieved 70 papers for rats, 34 for mice, 16 for rabbits, 11 for sheep, 5 for pigs and 3 papers for zebrafish. Although the popularity of rats is related to their established position in postmenopausal osteoporosis research, as evidenced by FDA guidelines (Thompson et al. 1995), murine models are increasingly used nowadays. Mice are considered to be an appropriate pre-clinical model of GIO. They share more than 95\% of the human genome and can be readily genetically manipulated to simulate specific human diseases. It is also possible to control for the variability found in humans and undertake experiments that would otherwise be impossible in humans. They also have the added advantage of being relatively easy and cost-effective to maintain. The adult mammalian skeleton undergoes a continuous remodelling cycle and some of the early preclinical studies using different species failed to appreciate this. More recent work has shown that the mouse shows a similar pattern to human GIO, with an early phase of osteoclast mediated bone resorption, followed by a more indolent phase of decreased osteoblastogenesis and bone formation (Yao et al. 2008). Unlike in humans, however, mice lack osteons (or the Haversian system) in cortical bone and therefore remodelling within this structure does not occur as it does in humans (Jilka 2013). Marked effects on bone structural parameters caused by GCs are more 
Table 1 Animal models of glucocorticoid-induced osteoporosis.

\begin{tabular}{|c|c|c|c|c|c|}
\hline Species & Sex + age & $\begin{array}{l}\text { GC type, duration, } \\
\text { administration, dose }\end{array}$ & $\begin{array}{l}\text { Body Weight } \\
\text { (compared to baseline) }\end{array}$ & $\begin{array}{l}\text { Bone } \\
\text { site }\end{array}$ & Bone imaging technique \\
\hline Mice, FVB & F, 3week & $\begin{array}{l}\text { Dex, } 28 \text { days working day SC } \\
14.3 \mu \mathrm{g} / \mathrm{mouse} / \mathrm{day}\end{array}$ & NA & Fem & $\mathrm{uCT}$ \\
\hline Mice, ICR & M, 6-8week & $\begin{array}{l}\text { Dex, } 28 \text { days, daily IP inj., } \\
2.5 \mathrm{mg} / \mathrm{kg} / \text { day }\end{array}$ & $\begin{array}{l}\text { No change in GC } \\
\text { group, }+15 \% \text { in } \\
\text { controls }\end{array}$ & Tib & $\begin{array}{l}\text { Histomorph, (tib), pQCT } \\
\text { (tib diaphysis) }\end{array}$ \\
\hline $\begin{array}{l}\text { Mice, mod Swiss Webster } \\
\text { backgrnd }\end{array}$ & M, 2 month & $\begin{array}{l}\text { Pred, } 21 \text { days, sc pellet, } 0.8,2.8 \\
\text { and } 4.0 \mathrm{mg} / \mathrm{kg} / \text { day }\end{array}$ & $\begin{array}{l}-20 \% \text { in GC groups, } \\
+24 \% \text { in controls }\end{array}$ & $\begin{array}{l}\text { Fem } \\
\text { LS }\end{array}$ & $\begin{array}{l}\text { Histomorph, (L4, fem } \\
\text { shaft); uCT (L5, distal } \\
\text { fem) }\end{array}$ \\
\hline Mice, Swiss Webster & M, 2 month & $\begin{array}{l}\text { Pred, } 21 \text { days, sc pellet, } 3.3 \text { mg/ } \\
\text { kg/day }\end{array}$ & $\begin{array}{l}-20 \% \text { in GC group; } \\
+25 \% \text { in controls }\end{array}$ & $\begin{array}{l}\text { Fem } \\
\text { LS }\end{array}$ & $\begin{array}{l}\text { Histomorph (L4, L5, fem } \\
\text { diaphysis); UCT (fem } \\
\text { diaphysis, L5) }\end{array}$ \\
\hline $\begin{array}{l}\text { Mice, WT littermates of } \\
\text { transgenic offspring }\end{array}$ & M, 8 week & Cort, 28 days, sc pellet, NA & NA & $\begin{array}{l}\text { Tib } \\
\text { LS }\end{array}$ & $\begin{array}{l}\text { Histomorph(prox tibia); } \\
\text { uCT (L3, tibia) }\end{array}$ \\
\hline Mice, CD1 Swiss White & M, 7-9week & $\begin{array}{l}\text { Cort, } 28 \text { days, sc pellet, } 15 \text { mg/ } \\
\text { kg/day }\end{array}$ & NA & $\begin{array}{l}\text { Tib } \\
\text { LS }\end{array}$ & uCT (L3, tibia) \\
\hline Mice, C57BL/6J + 129/SvJ & $F+M, 9$ week & $\begin{array}{l}\text { Cort, } 28 \text { days sc pellet every } \\
\text { week NA }\end{array}$ & $\begin{array}{l}+27 \% \text { in GC groups; } \\
+3 \% \text { in controls }\end{array}$ & Tib & $\mathrm{QCT}$ \\
\hline Mice, C57BL/6 & F, 8-10 week & $\begin{array}{l}\text { Dex, } 17 \text { days working day IP } \\
88 \mu \mathrm{g} / \mathrm{mouse} / \text { day }\end{array}$ & NA & Fem & $\mathrm{pQCT}$ \\
\hline Mice, C57BL/6J & F, 3 month & $\begin{array}{l}\text { Dex, } 84 \text { days thrice week IM } \\
2.1 \mathrm{mg} / \mathrm{kg} / \mathrm{day}\end{array}$ & $\begin{array}{l}\text { NA (at end GC group } \\
+22 \% \text { vs controls) }\end{array}$ & Tib & Histomorph,;CT \\
\hline Mice, Swiss Webster & M, 3 month & $\begin{array}{l}\text { Pred, } 28 \text { days, sc pellet, } 1.4,2.8 \\
\text { and } 5.6 \mathrm{mg} / \mathrm{kg} / \text { day }\end{array}$ & NA & $\mathrm{F}$ & Histomorph \\
\hline Mice, C57BL/6 & F, 4 month & $\begin{array}{l}\text { Pred, } 28 \text { days sc pellet } 1.4 \text {, } \\
2.1 \mathrm{mg} / \mathrm{kg} / \text { day }\end{array}$ & No change & $\begin{array}{l}\text { Fem } \\
\text { LS }\end{array}$ & $\begin{array}{l}\text { Histomorph (LS) } \\
\text { DXA (LS; fem) } \\
\text { uCT (LS) }\end{array}$ \\
\hline Mice, Swiss Webster & M, 4 month & $\begin{array}{l}\text { Pred, } 28 \text { days, sc pellet, } 2.1 \text { mg/ } \\
\text { kg/day }\end{array}$ & NA & LS & $\begin{array}{l}\text { Histomorph(L5); DXA (L? } \\
\text { in vivo) }\end{array}$ \\
\hline Mice, Swiss Webster & $\mathrm{F}, 5$ month & $\begin{array}{l}\text { Pred, } 10 \text { days sc pellet } 2.1 \text { mg/ } \\
\text { kg/day }\end{array}$ & NA & LS & Histomorph, DXA \\
\hline Mice, Swiss Webster & M, 5 month & $\begin{array}{l}\text { Pred, } 28 \text { days, sc pellet, } 5.0 \mathrm{mg} / \\
\text { kg/day }\end{array}$ & $\begin{array}{l}\text { No change by end } \\
\text { ( }-15 \% \text { after } 2 \text { weeks } \\
\text { in } \mathrm{GC} \text { gp) }\end{array}$ & Tib & Histomorph, ; uCT \\
\hline Mice, C57BL/6 & M, 6 month & $\begin{array}{l}\text { Pred, } 56 \text { days, sc pellet, } 2.8 \mathrm{mg} / \\
\text { kg/day }\end{array}$ & NA & $\begin{array}{l}\text { Fem } \\
\text { LS }\end{array}$ & uCT (L3, femoral diaphysis) \\
\hline Mice, C57BL/6 & M, 6 month & $\begin{array}{l}\text { Pred, } 28 \text { days, sc pellet, } 2.1 \text { mg/ } \\
\text { kg/day }\end{array}$ & NA & LS & $\begin{array}{l}\text { Histomorph, (L1-L4); uCT } \\
\text { (L5); DXA (L1-L4 in vivo) }\end{array}$ \\
\hline Mice, Swiss Webster & M, 6 month & $\begin{array}{l}\text { Pred, } 56 \text { days, sc pellet, } 5.0 \text { mg/ } \\
\text { kg/day }\end{array}$ & NA & Fem & $\mathrm{uCT}$ \\
\hline Mice, BALB/C & F, 7 month & $\begin{array}{l}\text { Dex, } 14 \& 21 \text { days daily IP 1.0, } \\
5.0,10 \mathrm{mg} / \mathrm{kg} / \text { day }\end{array}$ & No change & $\begin{array}{l}\text { Fem } \\
\text { Tib } \\
\text { LS }\end{array}$ & $\begin{array}{l}\text { Histomorph (Fem, Tib, L5) } \\
\text { uCT (Fem, Tib, LS) }\end{array}$ \\
\hline Mice, Swiss Webster & M, 6 month & $\begin{array}{l}\text { Pred, } 21 \text { days, sc pellet, } 1.4 \text { mg/ } \\
\text { kg/day }\end{array}$ & $\begin{array}{l}-10 \% \text { after } 1 \text { week, } \\
\text { regained initial } \\
\text { weight by study end } \\
\text { (no diff GC vs control } \\
\text { by end) }\end{array}$ & LS & Histomorph(L5); uCT (L5) \\
\hline
\end{tabular}




\section{Histomorphometry}

(GC vs controls)

NA

BV/TV $-45 \%$

MS/BS-50\%, BFR/BS-65\% in highest GC group only

L5: MS/BS $-46 \%$, BFR/BS $-60 \%$; Fem: diaphyseal endocortex: BFR/BS -91\%, diaphyseal periosteum -92\% Zero endocortical BFR/BS at tib

NA

NA

NA

NA

MS/BS -40-60\% (in two highest GC doses)

MS/BS: no diff, BFR/BS: $-36 \%$

BV/TV-66\%

BV/TV: $-23 \%, \mathrm{MS} / \mathrm{BS}:-86 \%, \mathrm{BFR} / \mathrm{NA}$

BS: $-90 \%$

BV/TV $-22 \%$, MS/BS $-61 \%$, BFR/ BS $-75 \%$

NA

BFR/BS-49\%

NA

Fem: BV/TV: no diff, Fem: MS/BS: $-62 \%$, Fem: BFR/BS: $-74 \%$ (at mid GC dose)

BV/TV -19\%, MS/BS-31\%, BFR/ BS- $80 \%$
HCT (GC vs control)

BV/TV: no diff

PQCT: no difference in vBMD, Cortical Thickness- $57 \%$

BV/TV $-22 \%$ in highest GC group only

L5: BV/TV -32\%; distal fem: BV/ TV: no diff

L3: BV/TV: no diff; tibial metaphysis: BV/TV: no diff; tib diaphysis: Cortical thickness: no diff

L3: BV/TV-33\%; tibia: BV/TV-56\%

Trab BMD: $-12 \% \mathrm{~F},-21 \% \mathrm{M}$ BV/

TV $-20 \% \mathrm{~F},-27 \% \mathrm{M}$ cort $\mathrm{VBMD}$

decreased, but not cort

thickness/bone area

Trab vBMD :+30\%, Cort thickness: $-9 \%$

BV/TV $-47 \%$

NA

BV/TV: no diff

Cort thickness: $-22 \%$

NA

BV/TV no difference

L3: BV/TV-25\%; femoral diaphysis: Cortical thickness $-20 \%$

BV/TV not diff

BV/TV no difference $(-30 \%$ at day 28)

Fem BV/TV: +11\%; LS: no diff

BV/TV-22\%

\section{Bone strength testing}

DXA (GC vs control)

NA

NA

NA

NA

NA

NA

NA

(GC vs control)

NA

NA

Axial compression (L6),

4-point-bend test (fem)

L6: Max Load $-48 \%$ and $-61 \%$ in 2 higher doses GC gps,

resp; no diff at fem

Axial compression (L6),

3-point-bend test (femur)

Max Load: L6: -24\%, fem: no diff

3-point-bend test (tib) Max Load: no diff

Ref

Postnov et al

(2009)

Du et al. (2011)

Yao et al. (2016)

Dai et al. (2015)

NA

NA

NA

NA

Axial compression (L6)

Axial compression (LS)

No diff

NA

from

baseline- $9 \%$ in

GC gp and $-4 \%$ in controls, (sig diff between grps)

aBMD: $-18 \%$

Axial compression (LS) Max Load: $-34 \%$

NA

NA

NA NA

aBMD-11\%

Axial compression (L6)

NA

NA

NA

Axial compression (L3)

Max Load: no dif
Li et al. (2016)

Henneicke et al. (2011)

Herrmann et al. (2009)

Tamura et al. (2015)

Grahnemo et al. (2015)

Cheng et al. (2015)

Jia et al. (2011)

Sato et al. (2016)

Plotkin et al. (2011)

Bouvard et al. (2013)

Fumoto et al. (2014)

Weinstein et al. (2011)

Yao et al. (2008)

McLaughlin et al. (2002)

Lane et al. (2005) 


\begin{tabular}{l|l|l|c|}
$\begin{array}{l}\text { Journal of } \\
\text { Endocrinology }\end{array}$ & $\begin{array}{l}\text { Animal models for GC effects on } \\
\text { skeleton }\end{array}$ & $\mathbf{2 3 6 : 1}$ \\
\hline
\end{tabular}

Table 1 Continued.

\begin{tabular}{|c|c|c|}
\hline Species & Sex + age & $\begin{array}{l}\text { GC type, duration, } \\
\text { administration, dose }\end{array}$ \\
\hline Mice, Swiss Webster & M, 7 month & $\begin{array}{l}\text { Pred, } 27 \text { days, sc pellet, } 0.7 \text { and } \\
2.1 \mathrm{mg} / \mathrm{kg} / \text { day }\end{array}$ \\
\hline
\end{tabular}

\begin{tabular}{|c|c|}
\hline $\begin{array}{l}\text { Body Weight } \\
\text { (compared to baseline) }\end{array}$ & $\begin{array}{l}\text { Bone } \\
\text { site }\end{array}$ \\
\hline $\begin{array}{l}\text { NA (tendency to lower } \\
\text { weights in GC grps by } \\
\text { end) }\end{array}$ & $\begin{array}{l}\text { Fem } \\
\text { LS }\end{array}$ \\
\hline
\end{tabular}

end)
Bone imaging technique
Histomorph ( $L$ ?, femur),
DXA (L? in vivo)
Mice, Black Swiss +129SvJ

Rabbits, Japanese white

Rabbits, New Zealand white

Rabbits, New Zealand white

Rabbits, New Zealand white

Rats, Wistar

Rats, Sprague-Dawley

Rats, Sprague-Dawley

Rats, Sprague-Dawley

Rats, Wistar

Rats, Sprague-Dawley

Rats, Sprague-Dawley

Rats, Wistar

Rats, Sprague-Dawley
M, 7 month

Pred, 28

kg/day

F, 6 month

F, 8 month

F, 8 month

M, 8 month

M, 2 month

F, 3 month

F, 3 month

M, 3 months

MP, 28 days, daily IM inj., $2.0 \mathrm{mg} / \mathrm{kg} / \mathrm{day}$

MP, 56 days, daily IM inj., $1.0 \mathrm{mg} / \mathrm{kg} /$ day

MP, 28 days, daily IM inj., $1.5 \mathrm{mg} / \mathrm{kg} /$ day

Dex, 84 days, twice a week IM inj., $0.9 \mathrm{mg} / \mathrm{kg} / \mathrm{day}$

Pred, 42 days, oral gavage every second day, $15 \mathrm{mg} / \mathrm{kg} /$ day

Dex, 84 days, twice a week IM No change inj., $0.7 \mathrm{mg} / \mathrm{kg} / \mathrm{day}$

MP, 56 days, thrice a week SC No change inj., $2.1 \mathrm{mg} / \mathrm{kg} /$ day

Pred, 90 days, daily oral gavage, $1.5,3.0$ and $6.0 \mathrm{mg} /$ kg/day

$+33 \%$ in GC groups; $+62 \%$ in controls
F, 3, 6, 12 month

Pred, 28 days, daily SC inj., 2.0 and $20 \mathrm{mg} / \mathrm{kg} / \mathrm{day}$

F, 6 month

F, 8 month

M, 8 month

M, NA $200-225 \mathrm{~g}$

(1)

Dex infusion
MP, 30 days, thrice a week SC No change (no details inj, $3.0 \mathrm{mg} / \mathrm{kg} /$ day

MP, 60 days, daily SC inj, 30 mg/ NA kg/day

MP, 42 days, weekly SC inj, NA $1.0 \mathrm{mg} / \mathrm{kg} /$ day
Fem

LS

Fem LS

LS

LS

Knee

IS

Tib

Multi sites

Tib

Fem

Tib

Fem

LS
$+9 \%,+3 \%$ No change in controls; $+5 \%$, no change, $-8 \%$ in high GC group $(3,6$,

12-month old mice, resp.)

$$
\text { shown) }
$$$$
\text { NA }
$$

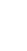

Tib

pQCT (tib metaphysis and diaphysis)

Tib

Total

Body

Fem

Femur

LS

Fem

Histomorph(tib)DXA (total body)

DXA

Histomorph (distal fem); DXA (L2-L4 in vivo)

Histomorph
Histomorph,(LS, Fem); pQCT (LS, Fem)

DXA (fem head and shaft), uCT (fem, L4)

DXA (L3-L4 in vivo), uCT (L3-4)

DXA (L3-L4, knee)

Histomorph (L3), DXA (L3-L4)

pQCT (tibial diaphysis)

DXA (head, upper limb, fem, trunk, rib, pelvis, spine, whole body)

Histomorph,(tib diaphysis); DXA (fem)

Histomorph (fem, tibia); DXA (fem, L5); uCT (L6)

$+8 \%$ in GC group, $+52 \%$ in controls 


\section{Histomorphometry}

(GC vs controls)

BV/TV-39\%, MS/BS-26\%, BFR/

BS-53\% (in higher GC group only)

\begin{abstract}
LS: BV/TV: $-31 \%$
LS: BFR/BS: $84 \%$

Fem: no difference
\end{abstract}

NA

NA

NA

BV/TV-39\%

NA

NA

MS/BS-60\%, BFR/BS-76\%

tib: BV/TV: no diff, MS/BS-27\% (high GC gp only), BFR/BS-52\% (all combined); fem: BV/TV: no diff, MS/BS-39\% (comb), BFR/ BS-38\% (comb)

NA

BV/TV-11\%, MS/BS-13\%, BFR/ BS-18\%

NA

BV/TV $-34 \%$

BV/TV-50\%

$\boldsymbol{\mu C T}$ (GC vs control)
NA

aBMD change

from base $-3,-7$,

$-9 \%$ in controls,

lower, higher GC dose groups, respectively (sig

diff between higher GC vs

control)

pQCT: vBMD no diff NA

Osteonecrosis after 8 weeks (4-week treatment +4-week wash out) in fem head BV/TV-17\%

NA

NA

Cortical vBMD $-2 \%$, Cortical thickness: no diff, SSI-25\%

NA

NA

BV/TV: no difference

Trab vBMD higher/lower/not diff (3/6/12-month old), Cortical VBMD unchanged in either group (only \% changes from baseline given)

aBMD: femoral

head $-33 \%$; fem

shaft- $22 \%$

aBMD-25\%

aBMD: spine-9\%;

knee-19\%

aBMD-27\%

NA

L5: no diff

NA
Bone strength testing

(GC vs control)

Ref

NA

Weinstein et al.

(1998)

Axial compression (LS); 3-point Hofbauer et al.

bend test (femur)

(2009)

Max Load: LS: $-29 \%$, Fem: no diff NA

Ax
Axial compression (L3-4) Max Load-19\%, no diff in Stiffness
NA

Axial compression (L4) Max Load-38\%, Stiffness-34\%

Lin et al. (2016)

NA

aBMD: spine-18\% NA

Baofeng et al. (2010)

Castañeda et al. (2008)

Yongtao et al.

(2014)

Yokote et al. (2008)

Jiang et al. (2016)

aBMD-5\% NA

aBMD: fem: $-8 \%$; Axial compression (L5),

Iwamoto et al. (2008)

3-point-bend test (fem) Max Load: fem: $-7 \%$ (no diff with lowest dose), L5: $-22 \%$; Stiffness: fem: $-17 \%$ (no diff with lowest dose), L5: data not shown

NA

Lin et al. (2014)

NA

aBMD-8\%

NA

Dalle Carbonare

et al. (2007)

3-point-bend test (femur) Max Load-27\%

aBMD $-1 \%$ in

NA

Bitto et al. (2009)

controls, $-10 \%$ in

GC (sig diff

between gps)

NA

NA
Wimalawansa \& Simmons (1998)

King et al. (1996)

aBMD, areal bone mineral density; BFR/BV, bone formation rate/bone surface; BV/TV, bone volume/tissue volume; Cort, corticosterone; Dex, dexamethasone; DXA, dual x-ray absorptiometry; F, female; Fem, femur; GC, glucocorticoid; Histomorph, histomorphometry; LS, lumbar spine, M, male; MAR, mineral apposition rate; MP, methylprednisolone; MS/BS, mineralizing surface/bone Surface; NA, not available; Pred, prednisolone; PQCT, peripheral quantitative $\mathrm{CT}$; $\mathrm{QCT}$, quantitative $\mathrm{CT}$; Tib, tibia; $\mathrm{UCT}$, micro-CT; $\mathrm{VBMD}$, volumetric $\mathrm{BMD}$. 
frequently observed in younger animals, but in order to avoid complications in bone measurements due to loss of weight caused by GC, it has been suggested that skeletally mature animals should be used to investigate GIO. Gene knockout and transgenic approaches have also established the usefulness of the mouse in determining which genes are critical for bone turnover (Rauch et al. 2010). The mouse has also been used effectively in other models of bone loss, such as androgen or oestrogen loss and ageing (Pogoda et al. 2005). However, with regard to bone density and quality, dogs appear to be most similar to humans and rats the least (Aerssens et al. 1998). Interestingly, in vivo and in vitro bone mineral imaging as well as scale mineralization studies in zebrafish were described as a very simple alternative to explore alterations in mineralization pathways to GC challenge (Barrett et al. 2006).

\section{Techniques to measure GIO}

Osteoporosis is defined as an alteration of bone structure leading to increased fragility and fracture rate. In humans, clinically significant fractures and inappropriately low BMD serve as diagnostic criteria for osteoporosis. There is no such consensus on criteria defining osteoporosis in animal models. As spontaneous fractures do not occur in most animal models, unlike in humans, suitable proxy outcome measures need to be utilized. The following methods have been used to describe changes in bone health after GC exposure:

\section{Bone histomorphometry}

Traditional methods to assess changes in bone structure include the evaluation of histological sections of mineralized bone. In basic osteoporosis research, lumbar vertebral bodies and long-bone (typically, femoral and tibial) metaphyses are examined to investigate trabecular (cancellous) bone changes, whereas cortical bone alterations are assessed within the diaphysis of long bones. In addition to the primary static measures, so-called dynamic parameters can also be calculated using the primary measures assessed on bone histological sections after appropriate fluorochrome labelling.

\section{Dual-energy x-ray absorptiometry}

Dual-energy x-ray absorptiometry (DXA) is widely used for BMD evaluation in the clinical as well as research setting.
DXA assesses areal BMD (aBMD=bone mineral content/ bone area). The precision of in vivo DXA scans has been shown to be very good in mice (coefficients of variation $<2 \%)$ at total body (excluding head), lumbar spine (L4-L5), whole femur and whole tibia sites (Iida-Klein et al. 2003). This enables longitudinal BMD observations to be used in murine osteoporosis studies. However, in studies, DXA scans have often been performed on different skeletal sites ex vivo as an outcome measure (Table 1). The main drawback of DXA is that there is no information on bone structure or quality. Bone mass increases with body mass, therefore, smaller and younger animals will have lower BMD compared to larger and older ones, but not necessarily more fragile bones. Since experimental drugs, such as GCs, may affect body weight or growth (as discussed later), size should be taken into account to prevent the introduction of bias regarding the effect on BMD. However, bone size adjustments are rarely undertaken in murine osteoporosis studies (none of the studies listed in Table 1).

\section{Peripheral quantitative computerized tomography and micro-computerized tomography}

By using peripheral quantitative computerized tomography (pQCT), true volumetric BMD can be assessed, that, together with bone architecture and geometry, allows for calculation of bone strength and structural indices. These indices correlate very well with whole bone strength when tested ex vivo (Siu et al. 2003, Kokoroghiannis et al. 2009). Micro-computerized tomography $(\mu \mathrm{CT})$ is normally used at a resolution of $1-10 \mu \mathrm{m}$ in rodents (Bouxsein et al. 2010). Major advantages compared to 2D histological sections are the 3D nature of the data, so that real mineralized bone matrix volumes in whole bone tissue volumes (BV/TV) can be assessed, faster data acquisition and larger bone region under investigation.

\section{Biomechanical testing and biochemical markers of bone metabolism}

Although the primary aim may be focused at the molecular, cellular, tissue or whole bone organ level, the crucial clinically relevant outcome of the numerous papers focusing on osteoporosis research is to increase bone strength and reduce fracture risk. Bone tissue is a complex and metabolically active structure and, at the organ level, bone continuously adapts to mechanical loading and other environmental factors to mitigate the stress and sustain its function. Therefore, none of the 
above mentioned parameters alone can sufficiently mirror actual bone health. Biomechanical testing is the only method capable of verifying whether a treatment may cause or prevent bone fragility. In laboratory animals, bone competence is usually tested through axial compression of the vertebral bodies or three-point bending of long bones (Jepsen et al. 2015).

Distinct biochemical markers in serum/plasma are also used to follow disease or drug-mediated changes in bone formation (Glendenning 2011).

\section{GC type and dose to induce osteoporosis}

Prednisolone (or prednisone), methylprednisolone and dexamethasone are the most frequent synthetic GC used in osteoporosis animal models (Table 1). However, they have distinct differences in potency. Although the following order from the most to least potent is in agreement with several studies (i.e., dexamethasone $>$ methylprednisolone $>$ prednisolone/ prednisone $>$ hydrocortisone/corticosterone), the relative efficacy may vary based on the assay or method of evaluation (Meikle \& Tyler 1977, Tanaka et al. 1994, Buttgereit et al. 2002). The relative efficacy and potency of GC may also depend on the system studied, for example the potency for effects on bone metabolism may be quite different to those on glucose and fat metabolism (Ahmed et al. 2002, Wallace et al. 2003). In addition, it is not yet clear whether genomic or non-genomic pathways play the major role in GIO (Hartmann et al. 2016). Altered bone structure was observed in two-month-old male mice treated with $15 \mathrm{mg} / \mathrm{kg} /$ day of corticosterone (Herrmann et al. 2009), but only $2.8 \mathrm{mg} / \mathrm{kg} /$ day of methylprednisolone was needed to induce similar changes in mice of same age and sex (Yao et al. 2016). Therefore, methylprednisolone appears to be more potent than corticosterone in osteoporosis induction. Another study showed decreases in bone density, bone formation rate and bone strength in 6-month-old C57BL/6 male mice treated with prednisolone $2.1 \mathrm{mg} / \mathrm{kg} /$ day over 28 days, but the same dose was not sufficient to induce significant changes in female mice (Weinstein et al. 2011). By contrast, the same prednisolone dose was used in female mice of similar age, but different strain (i.e., Swiss Webster), and significant decreases were observed in bone density, bone formation and bone strength after only 10 days (Plotkin et al. 2011). This highlights that sex- as well as strain-specific efficacy may be present with different GCs. Controlling for sex (male), strain (Swiss Webster) and route of administration (slow release subcutaneous pellets), 3-month-old mice required $5.6 \mathrm{mg} / \mathrm{kg} / \mathrm{day}$ of prednisolone, the highest dose tested, to induce a significant decrease in mineralizing surface/bone surface (MS/BS) and bone strength (Jia et al. 2011) whereas a decrease in MS/BS and BMD was observed in 7 -month-old mice challenged with $2.1 \mathrm{mg} / \mathrm{kg} /$ day of prednisolone (Weinstein et al. 1998). Therefore, mouse age and pubertal status may be an additional factor influencing the potency of the tested GCs. In humans a dose of dexamethasone of $1 \mathrm{mg}$ is equivalent to $6 \mathrm{mg}$ of prednisolone, therefore consideration of the dose used relative to clinical application is important.

It is also important when investigating GIO to describe the impact on both trabecular and cortical bone as there are discrepancies between data obtained at different sites, see Table 1.

\section{Route of administration in GIO models}

Osteoporosis is induced by systemic administration of GC. Many studies implemented regular intramuscular, intraperitoneal or subcutaneous injections, but single implantation of slow release subcutaneous pellet or oral gavage have also been used (Table 1). In rats of the same strain and age, daily oral gavage of GCs over a 90 day period (Lin et al. 2014) led to similar adverse effects on bone (as assessed by histomorphometry and aBMD) as thrice weekly subcutaneous injections of GC over 56 days (Iwamoto et al. 2008). By contrast, a much shorter period of intervention is necessary to induce osteoporosis with daily injections (Ogoshi et al. 2008) or continuous infusion through subcutaneously implanted osmotic pumps (King et al. 1996). Daily injections are stressful for the animals, which may negatively influence the outcome and ethical regulations in some countries may not allow multiple repeated injections over a long time period. For example, the injection of carrier alone (PEG 400) caused a 3-fold increase in serum corticosterone levels in mice, compared to a 5-10 fold increase induced by an intraperitoneal injection of $10 \mathrm{mg}$ corticosterone/kg body weight, $1 \mathrm{~h}$ after injection (Herrmann et al. 2009). This technique of administration would also not be acceptable to most patients in the clinical trial setting. Micro-osmotic pumps were found to have a large variation in residual volumes 21 days after implantation. With a filling volume of $250 \mu \mathrm{L}$, residual volumes containing active drug ranged from 50 to $180 \mu \mathrm{L}$, which indicated major differences in the flow-rate of individual pumps (Herrmann et al. 2009). Subcutaneous insertion of slow release pellets containing 
corticosterone leads to more consistent drug levels as compared to subcutaneous injections of corticosterone. Oral gavage seems to be less effective compared to daily injections or slow release subcutaneous pellets, but has the most translational relevance, as this would be the most accepted method of GC administration in the clinical setting. Whilst slow release pellet insertion may reduce unnecessary repetition of periodical injections over the study period their safety and efficacy needs further validation.

\section{Animal models of GC-induced growth retardation}

It is likely that different animal models are required to investigate GIO and growth retardation. Poor choice of model may result in misinterpretation of results and limited translational promise. For example, the young growing rat does not show any bone loss or changes in microarchitecture of trabecular bone and modelling is the prevailing activity; therefore, it is a poor model for human GIO (until at least 9 months of age when the transition to remodelling occurs). It does appear, however, to be a good model to mimic the growth retardation seen in children exposed to GC (Lelovas et al. 2008). For growth studies, the age and status of sexual maturity at the time of growth plate closure must also be considered. Unlike humans, bone acquisition and longitudinal bone growth continue in mice and rats after sexual maturity. Linear bone growth in rodents increases during the largest proportion of life expectancy in comparison with other species (Kilborn et al. 2002). Humans and primates (showing the second highest ratios of age at growth plate closure to life expectancy), cows and sheep are also considered adults at the age when growth plate closure occurs. By contrast, rabbits, dogs and cats would be described as very young adults at the time of physis closure. In mice, whilst the highest growth phase is from weaning until sexual maturation, body weight continues to increase in the mouse up to the end of the 52nd week and long-bone growth continues slowly after puberty (Jilka 2013). By contrast, New Zealand white rabbits begin sexual maturation at approximately 2 months of age and undergo epiphyseal fusion by approximately 6 months of age. Therefore, in order to induce growth retardation and allow for subsequent catch-up growth in one study, GC challenge was commenced when the rabbits were 5 weeks of age (Weise et al. 2001). Nevertheless, using rabbits at a young age proved problematic for Kugelberg and coworkers who were unable to sex them at 3 weeks of age and therefore had to use both males and females in their study (Kugelberg et al. 2005). This is important as imprinting (Jansson et al. 1985) by androgen secretion of the neonatal rodent brain has been shown to result in sex differentiation of body growth and, therefore, it is also important to consider which sex of animal is most relevant to the research question.

\section{Techniques to assess bone growth rate}

When studying mammalian growth, simple gross parameters such as weight, body or tail length have historically been used as proxies for growth rates (Hughes \& Tanner 1970), and are still routinely recorded when assessing growth in pre-clinical studies. These measurements can be very inaccurate, however, and dependent on other confounding factors (Melin et al. 2005). X-ray determination of the length of different long bones with the aid of anatomical landmarks (Weber et al. 1968) is a simple but more accurate proxy. Recent advances in imaging also mean that tibial/femoral length can be accurately measured using micro $(\mu)$ CT. This is often performed in conjunction with other measures of trabecular and cortical bone structure (Waarsing et al. 2004, Bouxsein et al. 2010). In addition, in vivo $\mu \mathrm{CT}$ is a noninvasive imaging technique that allows longitudinal bone growth to be evaluated over a period of weeks or months in the same animals and would therefore be well suited for monitoring GC-induced growth retardation. This can be a cost-effective and ethical method as it reduces the number of animals required for a study and also minimizes intrasubject variability. Potential drawbacks include the dose of ionizing radiation delivered through multiple scans and the potential for radiation associated tissue effects on the growing skeleton (Klinck et al. 2008, Laperre et al. 2011). Inclusion of a non-irradiated contralateral limb would clarify the magnitude of this potential issue. Also, by administering fluorescent labels (Owen et al. 2009) at known time intervals, the bone formation rate (BFR) at the chondro-osseous junction can be assessed visually under UV light, without the need for further staining or decalcification (Dobie et al. 2015). In addition to the methods used to assess the growth rate of the entire bone, measures of the tibial epiphyseal growth plate width have been used for over 50 years as a reliable proxy indicator of growth rate (Interlichia et al. 2010).

More recently, a number of investigators have used ex vivo models such as rodent metatarsals in culture 
(Mårtensson et al. 2004, Mushtaq et al. 2004). For example, when fetal mouse metatarsals were cultured for up to 10 days with either daily or alternate-day dexamethasone at $10^{-6} \mathrm{M}$, dexamethasone-treated bones paralleled control bone growth rate until day 8 when their rate of growth decreased resulting in a total length that was significantly reduced from controls at days 8 and 10 (Mushtaq et al. 2004).

It is well established that the rate of linear bone growth is dependent on growth plate chondrocyte proliferation, matrix turnover and changes in chondrocyte shape and size (Hunziker \& Schenk 1989, Farquharson \& Jefferies 2000). Advances in quantitative histology now enable the growth plate to be scrutinized in greater detail to assess the contribution of the different chondrocyte activities to overall growth rate. Whilst quantitative histology techniques were developed in the 1970s to assess the relationship between cell division in growth cartilage and overall bone growth, chondrocyte proliferation is now routinely quantified by the immunohistochemical detection of BrdU incorporation into proliferating cells in tissue sections of the growth plate (Farquharson \& Loveridge 1990). Cell death of hypertrophic chondrocytes within the growth plate is also required for physiological bone growth and the TUNEL assay allows the detection and quantification of apoptotic cells within a population of chondrocytes (Kyrylkova et al. 2012).

\section{GC type and dose to induce growth retardation}

The inquiry was performed on PubMed, with 'growth retardation' or 'growth', 'glucocorticoids' and 'animal name' used as MeSH terms. When summarising the data, we have not included studies where only gross body measurement parameters were taken as a subset of a larger study. Studies where only an abstract was available were also excluded. Where the same groups have published multiple work using the same species and methodology, only the initial data has been represented in Table 2 .

As shown in Table 2, dexamethasone was the most frequently used GC in the growth retardation models that we reviewed. Method of administration and dosage varied greatly, consistent with the GIO models. Rodents were used in the majority of studies. Four of the studies administered subcutaneous injections of dexamethasone to mice of between 3 and 5 weeks of age. All used daily injections, except for one, where a 5-times weekly regimen was followed (Rooman et al. 1999). The length of course varied from 7 to 28 days and the dose used varied from approximately $0.02 \mathrm{mg} / \mathrm{kg} /$ day to $5 \mathrm{mg} / \mathrm{kg} /$ day. In one of the studies, where three varying doses were used, the lowest dose of $0.2 \mu \mathrm{g}$ (approximately $0.02 \mathrm{mg} / \mathrm{kg} /$ day) did not cause significant growth reduction, but both the $2 \mu \mathrm{g}$ and $20 \mu \mathrm{g}$ doses caused similar growth retardation (Rooman et al. 1999). No differing side effects were reported in the two groups. When a dose of $2 \mathrm{mg} / \mathrm{kg} /$ day was used, body weight was reduced only in males and femur length only in females, whilst a significant reduction in body weight was demonstrated by day 3 using $5 \mathrm{mg} / \mathrm{kg} /$ day in females in a different study (Owen et al. 2009). It would, therefore, appear that there is a sex difference in response to GCs and that an optimal dose would be greater than $2 \mathrm{mg} / \mathrm{kg} /$ day to ensure significant growth retardation in both sexes. However, the rapid catabolic response with a reduction in body weight by day 3 seen with a dose of $5 \mathrm{mg} / \mathrm{kg} /$ day would suggest the need for close monitoring (Owen et al. 2009).

We reviewed 8 studies using rats, usually either Wistar or Sprague-Dawley and up to 4 months of age at study induction. All except two studies used only male rats. Length of course varied greatly from 4 to 90 days. In one of the studies using prednisolone, $10 \mathrm{mg} / \mathrm{kg} / \mathrm{day}$ was originally chosen (after a previous study by the same authors demonstrated no effect on cortical bone using $5 \mathrm{mg} / \mathrm{kg} /$ day (Ortoft et al. 1992)) but after observing unexpectedly high weight loss, the dose was decreased to $5 \mathrm{mg} / \mathrm{kg} /$ day. Using $5 \mathrm{mg} / \mathrm{kg} /$ day they were able to demonstrate reduced longitudinal bone growth of the lumbar vertebrae. This highlights one of the problems of using body weight as a reflection of growth. GC can show a dual metabolic effect on body weight, depending on the dosage, method of administration and length of treatment. High dosages can cause a catabolic effect and loss in body weight whereas lower dosages can cause an increase in appetite and associated weight gain (as frequently seen in humans). For example, $1 \mathrm{mg} / \mathrm{kg}$ single dose of dexamethasone given to piglets caused accelerated growth at 18 days of age (Carroll 2001). Piglets are also noted to have a metabolic response to GCs that closely mimics the response observed in infants and children receiving long-term GC therapy (Ward et al. 1998). One of the studies using Wistar rats demonstrated inhibition of growth after only 10 days of either inhaled budesonide or fluticasone (Kemer et al. 2015), even at a dose of only $50 \mu \mathrm{g}$. This is particularly relevant when considering that http://joe.endocrinology-journals.org https://doi.org/10.1530/JOE-17-0361
C) 2018 Society for Endocrinology Published by Bioscientifica Ltd.
Printed in Great Britain 
¿

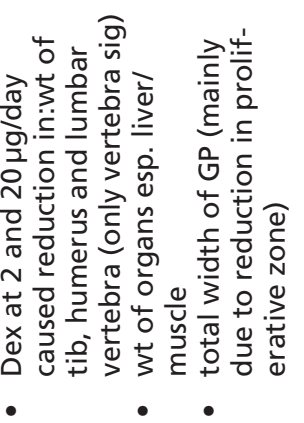
号高辛产
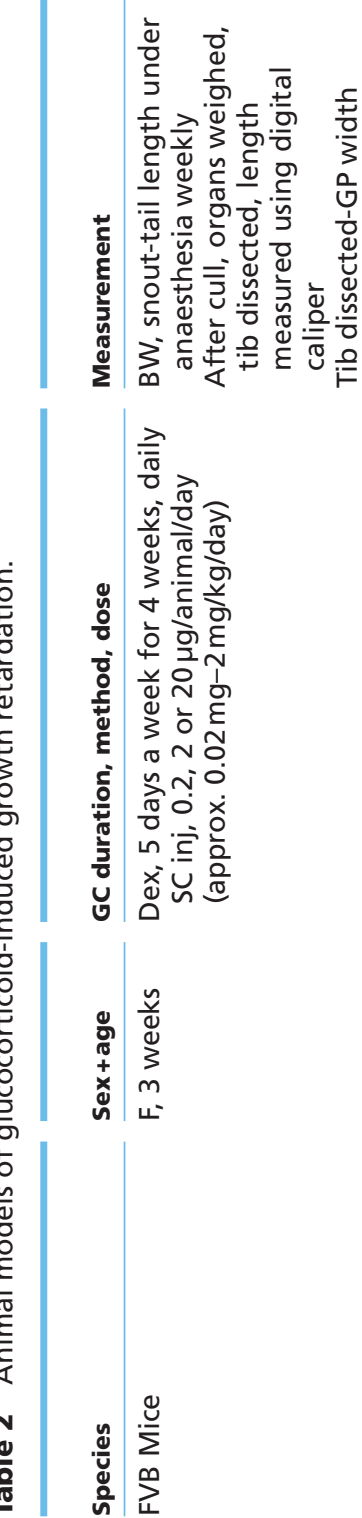

http://joe.endocrinology-journals.org https://doi.org/10.1530/JOE-17-0361

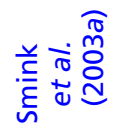

ờ

离

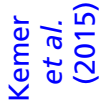

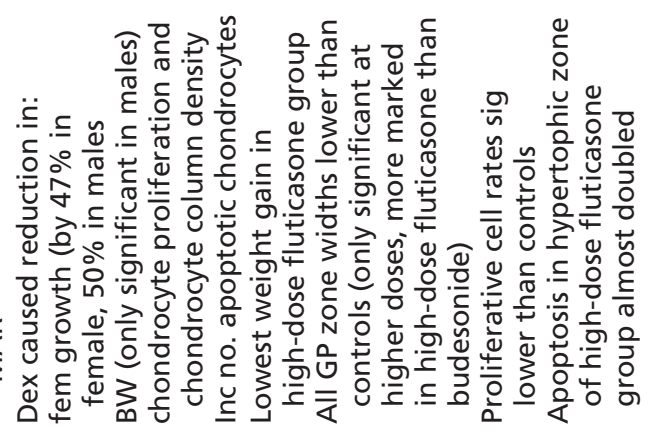

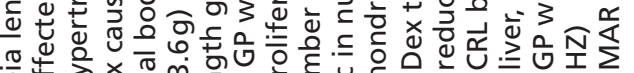

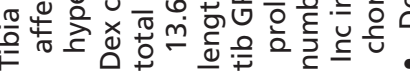
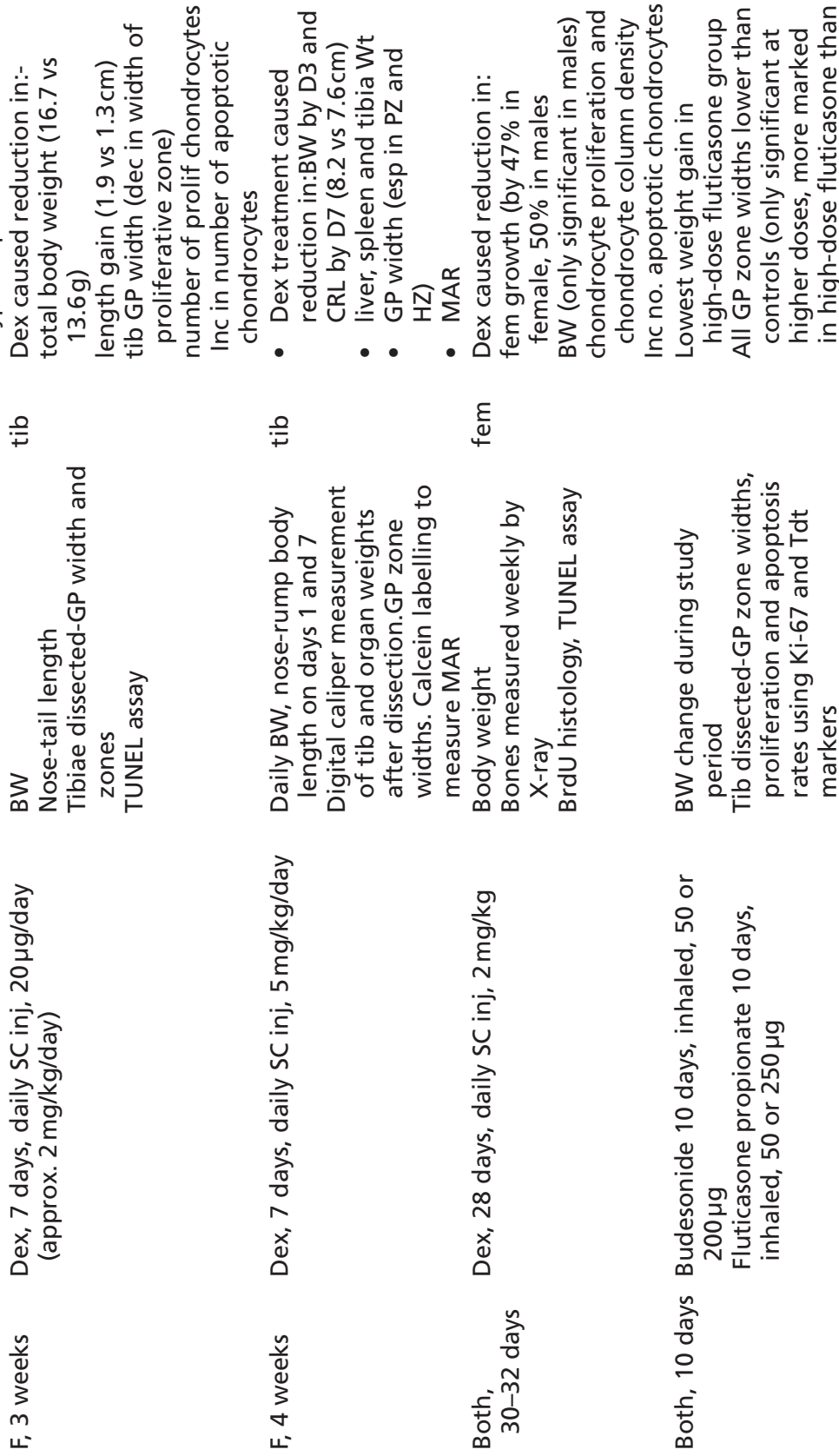

$\frac{\mathscr{g}}{\underline{\varepsilon}}$

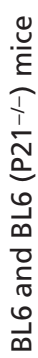
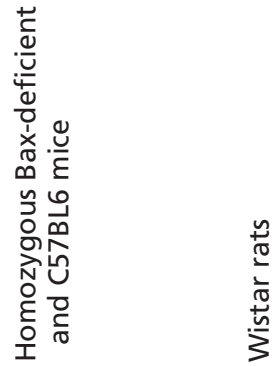


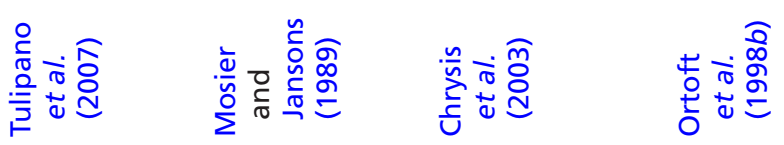

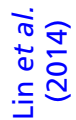

胥这

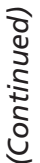

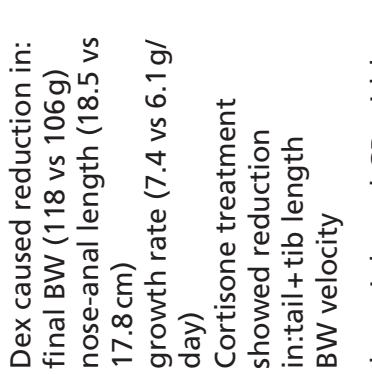

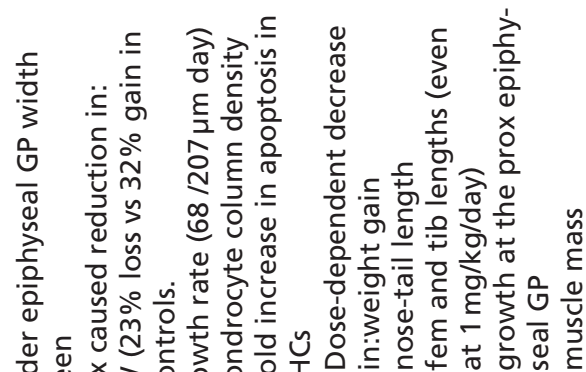

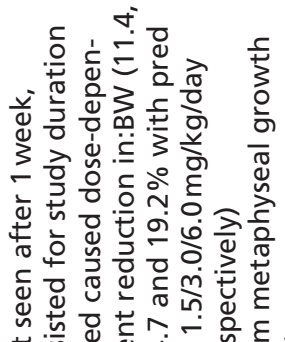
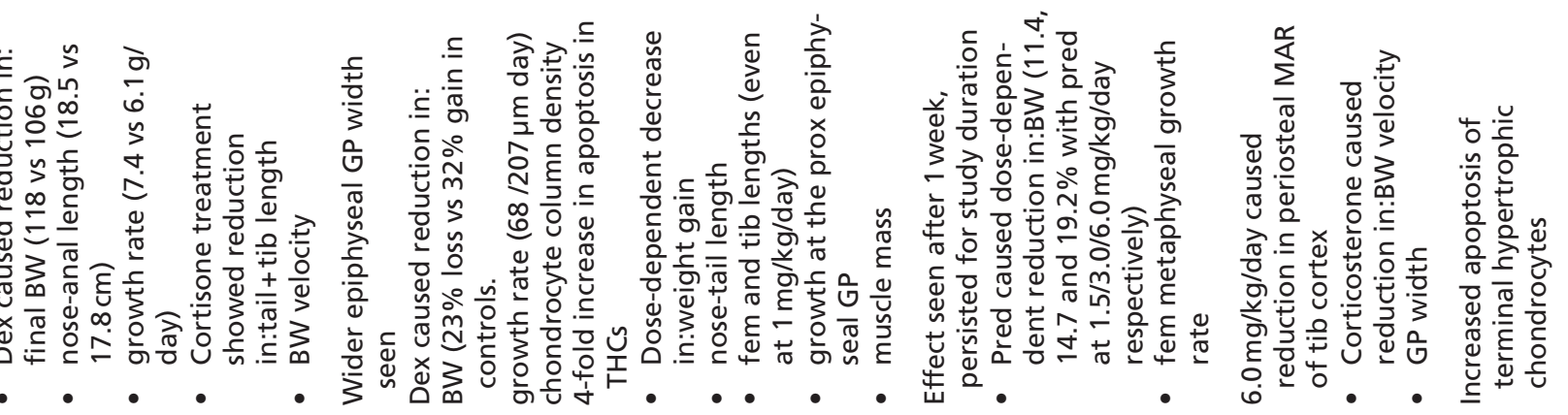

웉

$\stackrel{0}{=}$

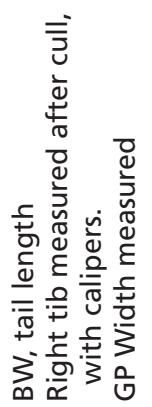

离

$\stackrel{m}{N}$

$\Sigma$

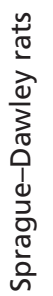

http://joe.endocrinology-journals.org https://doi.org/10.1530/JOE-17-0361
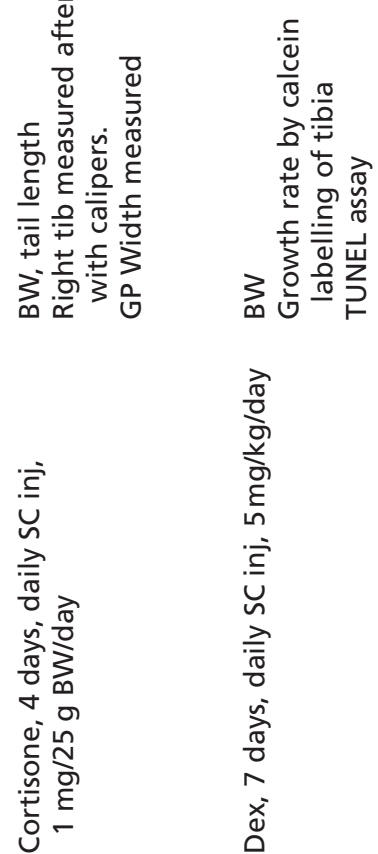

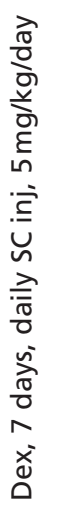

$\tilde{\pi}$
$\frac{n}{0}$
$\hat{m}$
$\Sigma$

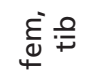
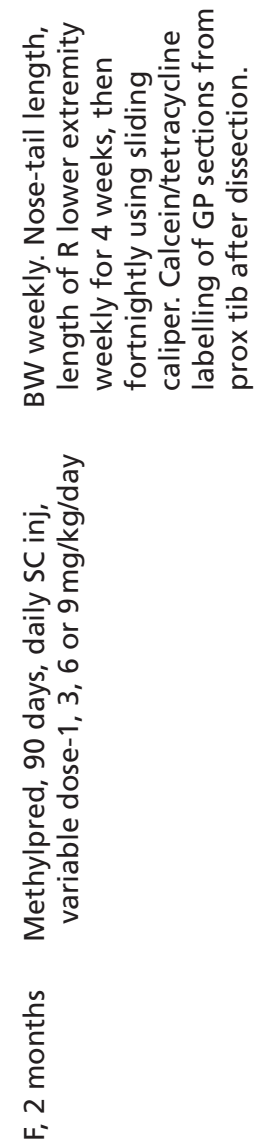

$\frac{\overbrace{}^{2}}{2}$ $\underbrace{\varepsilon}_{4}$

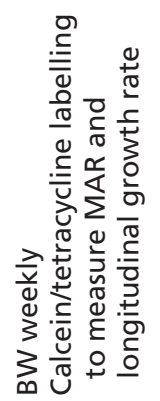

$\stackrel{0}{7}$
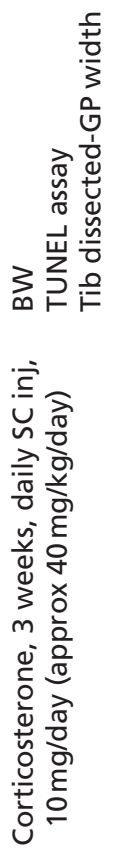

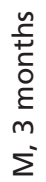
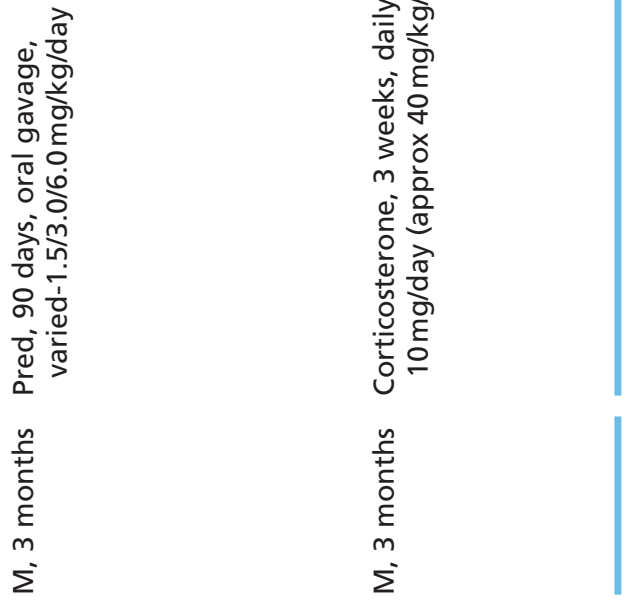

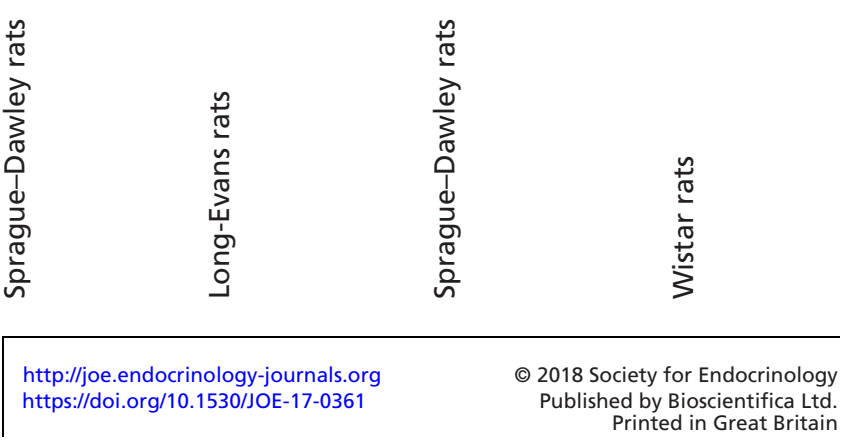

0
0
$\frac{0}{0}$
$\frac{\pi}{3}$
0
0
0
0
0
$\frac{\pi}{0}$
0

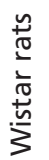




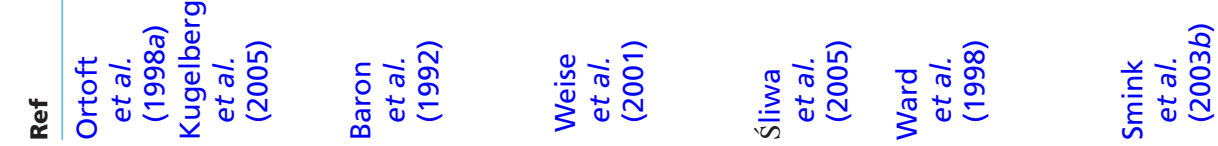

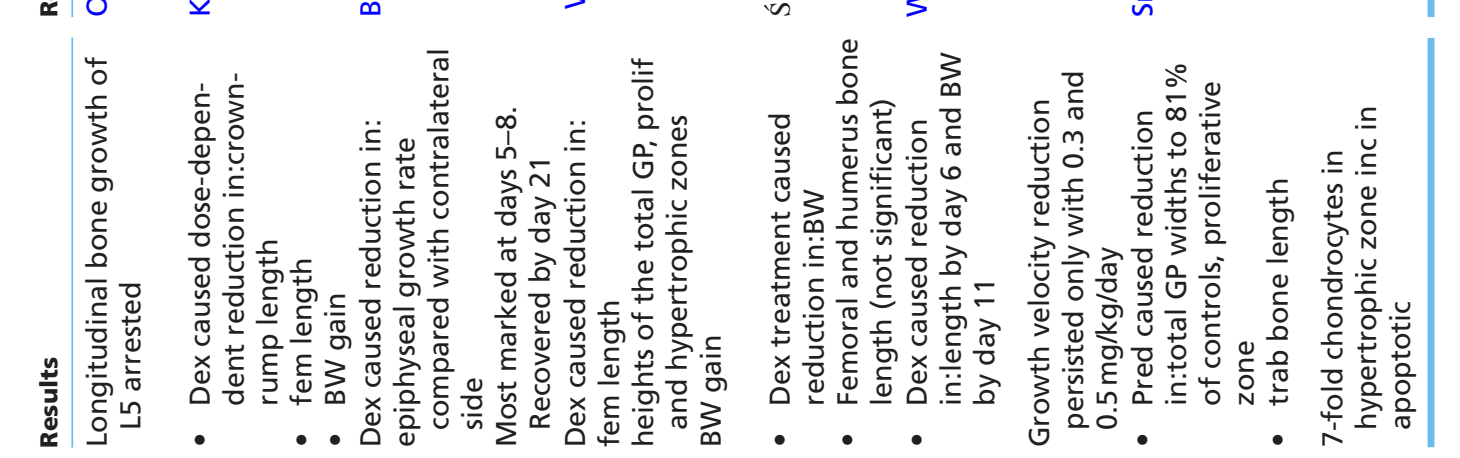
|

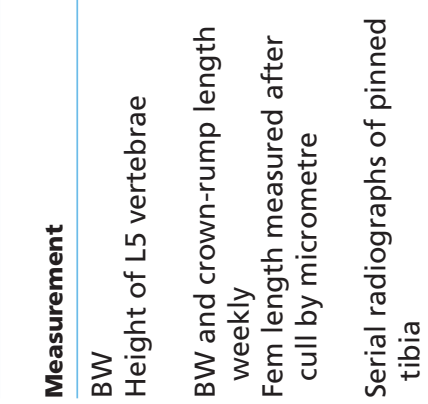
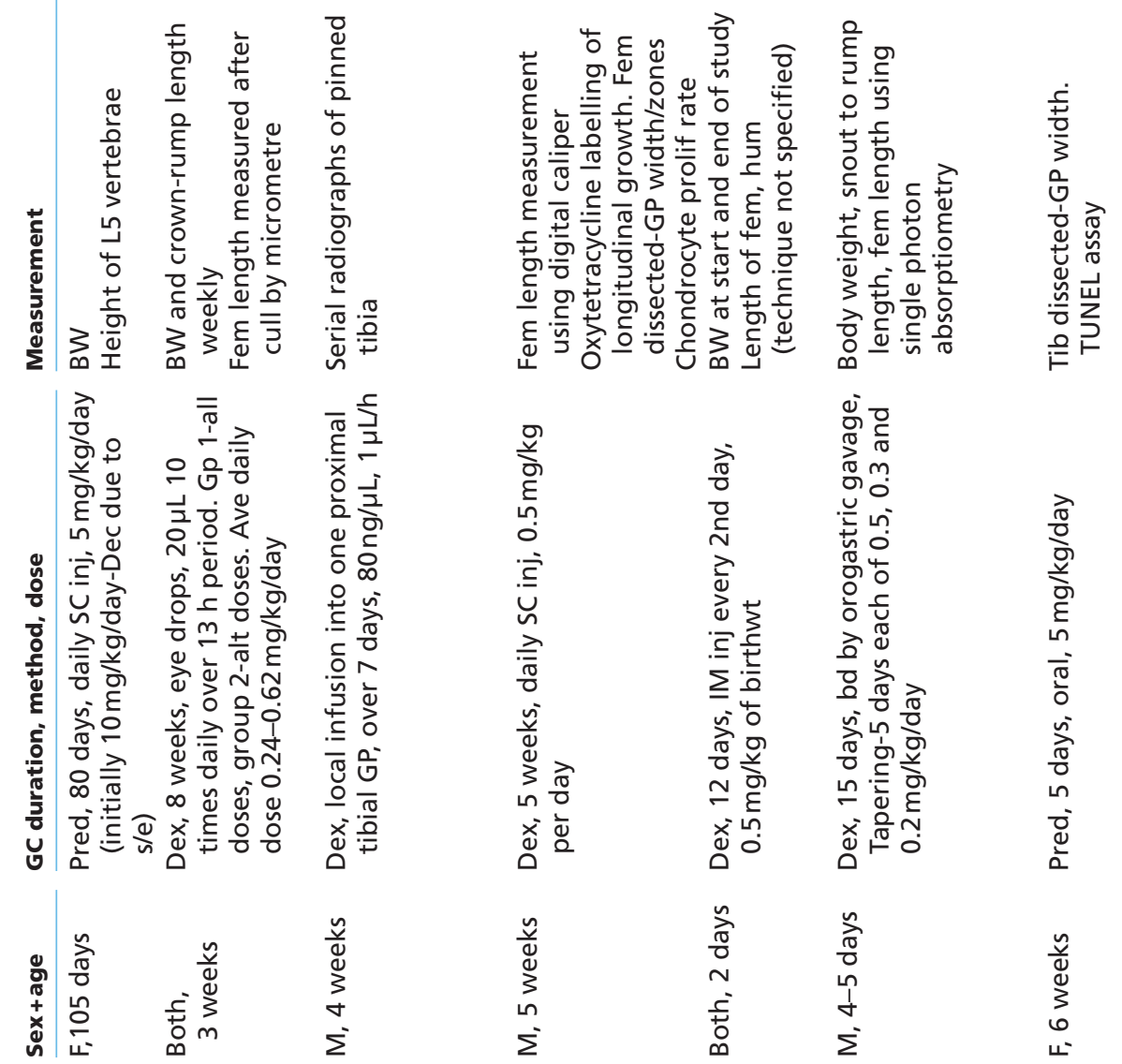

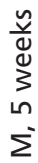

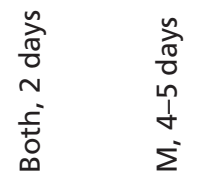

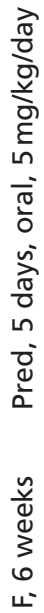
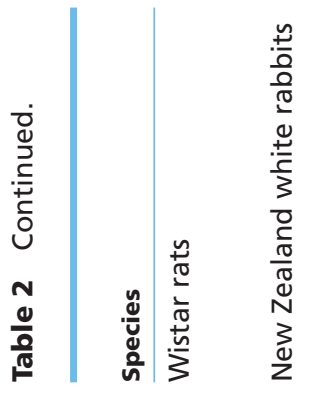

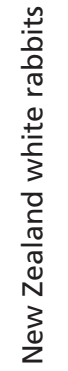
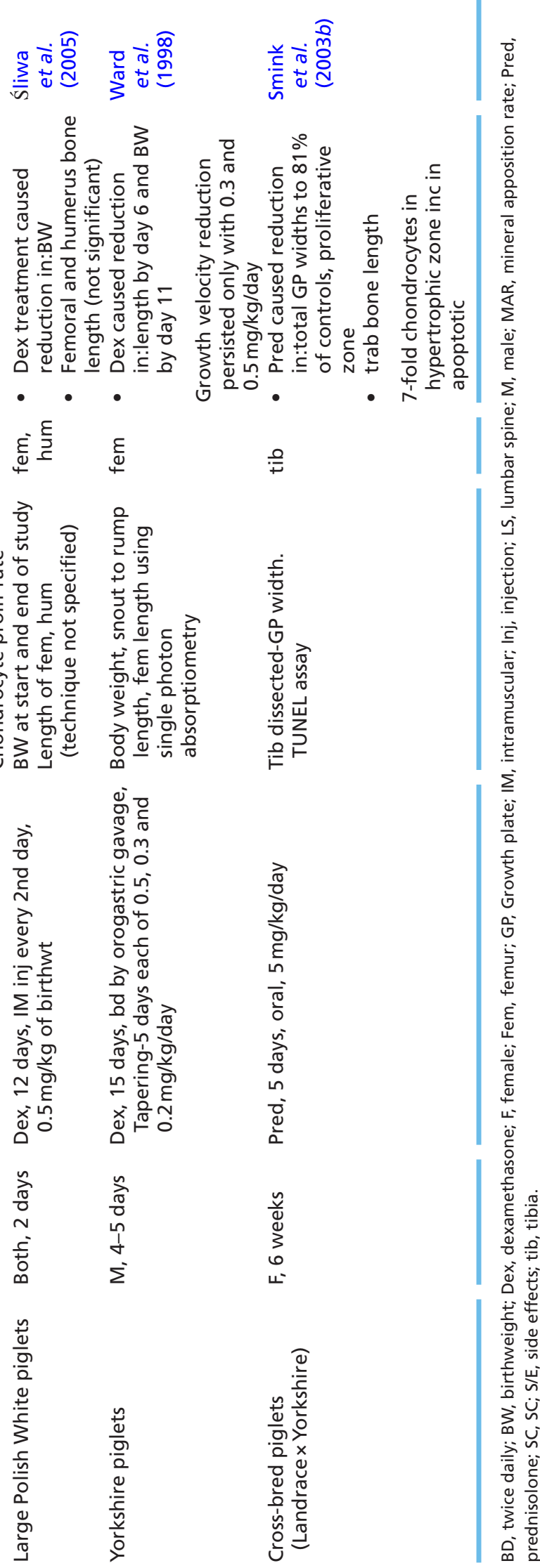
inhaled GCs are the treatment of choice for persistent asthma symptoms in both children and adults.

Decreased bone growth has been demonstrated even at concentrations as low as $1 \mathrm{mg} / \mathrm{kg} / \mathrm{day}$ in a study of rats, where doses of up to $9 \mathrm{mg} / \mathrm{kg} /$ day of methylprednisolone were used (Ortoft et al. 1998a). In this study there was no discernible dose-specific side effects although serum insulin levels were reduced in all groups. These authors also noted that the catabolic effect of $9 \mathrm{mg} / \mathrm{kg} /$ day of methylprednisolone (Ortoft et al. 1998b) by daily subcutaneous injection was less than that noted when a $5 \mathrm{mg}$ of depot prednisolone was used in rats of a similar age (Ortoft et al. 1998a). This suggests that routes of administration must also be considered.

Three studies were reviewed which used rabbits; each of these used dexamethasone, but via a different method of administration (eye drops, local infusion and daily subcutaneous injection) therefore they cannot be directly compared. However, all studies reported significant reductions in growth within the dexamethasone-treated groups. All rabbits were aged 5 weeks or less at study induction and all were aged 11 weeks or less at time of cull. In the only pre-clinical model to use a topical method of GC administration, significant effects on growth were demonstrated (Kugelberg et al. 2005).

Three studies used piglets, all of whom were less than 7 weeks of age at the end of the study. Again a variety of routes of GC administration were used. It would appear that a dose of $0.25 \mathrm{mg} / \mathrm{kg} / \mathrm{day}$ of dexamethasone is insufficient to induce bone growth retardation in young piglets (Śliwa et al. 2005). In a similar study, a reduction in growth velocity persisted only when piglets were dosed with $0.3 \mathrm{mg} / \mathrm{kg} / \mathrm{day}$ and above (Ward et al. 1998) and when prednisolone, at an equivalent dexamethasone dose of $0.75 \mathrm{mg} / \mathrm{kg} /$ day was used, a significant change in growth plate histology was seen (Smink et al. 2003b).

It appears that higher equivalent doses of GCs are used in rodents compared to larger mammals such as rabbits and piglets. In young mice, an optimal dose of dexamethasone when administered by daily subcutaneous injection seems to be between 2 and $5 \mathrm{mg} / \mathrm{kg} /$ day. This review demonstrates that there are a varied number of different methods that can be employed effectively to cause GC-induced growth retardation. However, unlike the review of GIO, we found no studies using implantable pellets or osmotic mini-pumps that measured growth parameters and therefore further studies are required to clarify their effectiveness of these delivery routes in causing growth retardation. Having highlighted the pitfalls of using the gross parameter body weight as a marker of growth; we propose that any future studies should also use other confirmatory parameters of growth such as bone length measurements, BFR or growth plate histology.

\section{Genetically engineered animal models}

Global deletion of GR is lethal and mice die of respiratory failure due to lung atelectasis on the first day of life (Cole et al. 1995) therefore it is not possible to create a complete GR-knockout model. However, tissue-specific genetically modified mouse models can be useful to tease out the effect of GCs on interlinked reactions between the different types of bone cells. For example, deleting osteoblast-specific GR conferred protection from GIO, whilst deleting osteoclast-derived GR had no effect (Rauch et al. 2010). Development of col 2.3 and col 3.6 hydroxysteroid dehydrogenase (HSD) 2 transgenic mouse models that activate 11 $\beta$-HSD2 in osteoblasts showed decreased vertebral trabecular and femoral cortical bone mass, without any change in serum GC levels (Liu et al. 2004), thus implicating a role for endogenous GC signalling within the osteoblast for optimal bone mass acquisition.

\section{Conclusion}

In this review, we have demonstrated that there are specific outcome measures that should be assessed when investigating either GIO or GC-induced growth retardation. We carried out a literature review with the aim of determining the most appropriate animal model to use when demonstrating the effects of GC on growth and bone structure, but results are too heterogeneous to enable one specific model to be advocated over another in all situations. However, there is sufficient evidence to recommend that investigation of GC-induced growth retardation in mice should be performed using dexamethasone $2-5 \mathrm{mg} / \mathrm{kg} /$ day by daily subcutaneous injection, and the outcome measures should include serial lengths (using consistent measuring technique) and/or growth plate width and BFR; the measurement of body weight for assessing linear growth is too inaccurate. When investigating GIO, there is insufficient evidence to recommend one specific mode of delivery over another, but in most studies, a dose of prednisolone $2-5 \mathrm{mg} / \mathrm{kg} /$ day in mice has been sufficient. Recommended 
outcome measures include volumetric BMD (by pQCT or $\mu \mathrm{CT}$ rather than by DXA for greater accuracy) and bone biomechanical testing to mimic fracture rate in clinical studies.

\section{Declaration of interest}

Diurnal research grant, Novo Nordisk-data monitoring board and educational meetings, Kyowa Kirin, consultancy (S F A).

\section{Funding}

C W, S F A and C F are supported by the Medical Research Council (MRC) (MR/N020588/1). S C W and S F A are supported by the Chief Scientist Office (CSO) (CAF/DMD/14/01). L S is supported by the Swedish Research Council project 2015-02406. O S is partly supported by an ESPE Research Fellowship, sponsored by Novo Nordisk A/S. F Z is supported by funding from the Swedish Research Council, Swedish Society for Medical Research, Swedish Childhood Cancer Foundation, Sällskapet Barnavård, HKH Kronprinsessan Lovisas Förening för Barnasjukvård/Stiftelsen Axel Tielmans Minnesfond. We are grateful to the Biotechnology and Biological Sciences Research Council (BBSRC) for Institute Strategic Programme Grant Funding (BB/J004316/1; BBS/E/D/20221657) to CF.

\section{Author contribution statement}

All authors drafted the outline for the manuscript. C W and O S wrote the first draft. S F A, C F, S C W, L S and F Z revised and approved the final version.

\section{References}

Aerssens J, Boonen S, Lowet G \& Dequeker J 1998 Interspecies differences in bone composition, density, and quality: potential implications for in vivo bone research. Endocrinology 139 663-670. (https://doi. org/10.1210/endo.139.2.5751)

Ahmed SF, Tucker P, Mushtaq T, Wallace AM, Williams DM \& Hughes IA 2002 Short-term effects on linear growth and bone turnover in children randomized to receive prednisolone or dexamethasone. Clinical Endocrinology 57 185-191. (https://doi.org/10.1046/j.13652265.2002.01580.x)

Allen DB, Mullen M \& Mullen B 1994 A meta-analysis of the effect of oral and inhaled corticosteroids on growth. Journal of Allergy and Clinical Immunology 93 967-976. (https://doi.org/10.1016/S00916749(94)70043-5)

Amiche MA, Albaum JM, Tadrous M, Pechlivanoglou P, Lévesque LE, Adachi JD, Cadarette SM, Article O, Amiche MA, Albaum JM, et al. 2016 Efficacy of osteoporosis pharmacotherapies in preventing fracture among oral glucocorticoid users : a network. Osteoporosis International 27 1989-1998. (https://doi.org/10.1007/s00198-0153476-4)

Baofeng L, Zhi Y, Bei C, Guolin M, Qingshui Y \& Jian L 2010 Characterization of a rabbit osteoporosis model induced by ovariectomy and glucocorticoid. Acta Orthopaedica 81 396-401. (https://doi.org/10.3109/17453674.2010.483986)

Baron J, Huang Z, Oerter KE, Bacher JD \& Cutler GB 1992 Dexamethasone acts locally to inhibit longitudinal bone growth in rabbits. American Journal of Physiology 263 E489-E492.
Barrett R, Chappell C, Quick M \& Fleming A 2006 A rapid, high content, in vivo model of glucocorticoid-induced osteoporosis. Biotechnology Journal 1 651-655. (https://doi.org/10.1002/biot.200600043)

Biggar WD, Harris VA, Eliasoph L \& Alman B 2006 Long-term benefits of deflazacort treatment for boys with Duchenne muscular dystrophy in their second decade. Neuromuscular Disorders 16 249-255. (https://doi. org/10.1016/j.nmd.2006.01.010)

Bitto A, Burnett B, Polito F, Levy R, Marini H, Di Stefano V, Irrera N, Armbruster M, Minutoli L, Altavilla D, et al. 2009 Genistein aglycone reverses glucocorticoid-induced osteoporosis and increases bone breaking strength in rats: a comparative study with alendronate. British Journal of Pharmacology 156 1287-1295. (https://doi. org/10.1111/j.1476-5381.2008.00100.x)

Blodgett FM, Burgin L, Iezzoni D, Gribetz D \& Talbot NB 1956 Effects of prolonged cortisone therapy on the statural growth, skeletal maturation and metabolic status of children. New England Journal of Medicine 254 636-641. (https://doi.org/10.1056/ NEJM195604052541402)

Bothwell JE, Gordon KE, Dooley JM, MacSween J, Cummings EA \& Salisbury S 2003 Vertebral fractures in boys with Duchenne muscular dystrophy. Clinical Pediatrics 42 353-356. (https://doi. org/10.1177/000992280304200408)

Bouvard B, Audran M, Legrand E \& Chappard D 2009 Ultrastructural characteristics of glucocorticoid-induced osteoporosis. Osteoporosis International 20 1089-1092. (https://doi.org/10.1007/s00198-0090864-7)

Bouvard B, Gallois Y, Legrand E, Audran M \& Chappard Glucocor D 2013 Glucocorticoids reduce alveolar and trabecular bone in mice. Joint Bone Spine 80. (https://doi.org/10.1016/j.jbspin.2012.01.009)

Bouxsein ML, Boyd SK, Christiansen BA, Guldberg RE, Jepsen KJ \& Müller R 2010 Guidelines for assessment of bone microstructure in rodents using micro-computed tomography. Journal of Bone and Mineral Research 25 1468-1486. (https://doi.org/10.1002/jbmr.141)

Buttgereit F, da Silva JAP, Boers M, Burmester G-R, Cutolo M, Jacobs J, Kirwan J, Köhler L, Van Riel P, Vischer T, et al. 2002 Standardised nomenclature for glucocorticoid dosages and glucocorticoid treatment regimens: current questions and tentative answers in rheumatology. Annals of the Rheumatic Diseases 61 718-722. (https://doi.org/10.1136/ard.61.8.718)

Canalis E 2005 The fate of circulating osteoblasts. New England Journal of Medicine 352 2014-2016. (https://doi.org/10.1056/NEJMe058080)

Canalis E, Bilezikian JP, Angeli A \& Giustina A 2004 Perspectives on glucocorticoid-induced osteoporosis. Bone 34 593-598. (https://doi. org/10.1016/j.bone.2003.11.026)

Canalis E, Mazziotti G, Giustina A \& Bilezikian JP 2007 Glucocorticoidinduced osteoporosis: pathophysiology and therapy. Osteoporosis International 18 1319-1328. (https://doi.org/10.1007/s00198-0070394-0)

Carroll JA 2001 Dexamethasone treatment at birth enhances neonatal growth in swine. Domestic Animal Endocrinology 21 97-109. (https://doi.org/10.1016/S0739-7240(01)00107-2)

Castañeda S, Calvo E, Largo R, González-González R, de la Piedra C, Díaz-Curiel M \& Herrero-Beaumont G 2008 Characterization of a new experimental model of osteoporosis in rabbits. Journal of Bone and Mineral Metabolism 26 53-59. (https://doi.org/10.1007/s00774-0070797-1)

Cheng Y, Wang W-L \& Liang J-J 2015 Genistein attenuates glucocorticoidinduced bone deleterious effects through regulation Eph/ephrin expression in aged mice. International Journal of Clinical and Experimental Pathology 8 394-403.

Chrysis D, Ritzen EM \& Sävendahl L 2003 Growth retardation induced by dexamethasone is associated with increased apoptosis of the growth plate chondrocytes. Journal of Endocrinology 176 331-337. (https://doi. org/10.1677/joe.0.1760331)

Cole TJ, Blendy JA, Monaghan AP, Krieglstein K, Schmid W, Aguzzi A, Fantuzzi G, Hummler E, Unsicker K \& Schütz G 1995 Targeted 
disruption of the glucocorticoid receptor gene blocks adrenergic chromaffin cell development and severely retards lung maturation. Genes and Development 9 1608-1621. (https://doi.org/10.1101/ gad.9.13.160)

Crofton PM, Ahmed SF, Wade JC, Stephen R, Elmlinger MW, Ranke MB, Kelnar CJH \& Wallace WHB 1998 Effects of intensive chemotherapy on bone and collagen turnover and the growth hormone axis in children with acute lymphoblastic leukemia. Journal of Clinical Endocrinology and Metabolism 83 3121-3129. (https://doi.org/10.1210/ jcem.83.9.5133)

Dai W, Jiang L, Lay Y-AE, Chen H, Jin G, Zhang H, Kot A, Ritchie RO, Lane NE \& Yao W 2015 Prevention of glucocorticoid induced bone changes with beta-ecdysone. Bone $\mathbf{7 4} 48-57$. (https://doi. org/10.1016/j.bone.2015.01.001)

Dalle Carbonare L, Bertoldo F, Valenti MT, Zordan S, Sella S, Fassina A, Turco G, Realdi G, Lo Cascio V \& Giannini S 2007 Risedronate prevents the loss of microarchitecture in glucocorticoid-induced osteoporosis in rats. Journal of Endocrinological Investigation $\mathbf{3 0}$ 739-746. (https://doi.org/10.1007/BF03350811)

Ding M, Cheng L, Bollen P, Schwarz P \& Overgaard S 2010 Glucocorticoid induced osteopenia in cancellous bone of sheep. Spine 35 363-370. (https://doi.org/10.1097/BRS.0b013e3181b8e0ff)

Dobie R, Ahmed SF, Staines KA, Pass C, Jasim S, MacRae VE \& Farquharson C 2015 Increased linear bone growth by GH in the absence of SOCS2 is independent of IGF-1. Journal of Cellular Physiology 230 2796-2806. (https://doi.org/10.1002/jcp.25006)

Du J, Cheng B, Zhu X \& Ling C 2011 Ginsenoside Rg1, a novel glucocorticoid receptor agonist of plant origin, maintains glucocorticoid efficacy with reduced side effects. Journal of Immunology 187 942-950. (https://doi.org/10.4049/ jimmunol.1002579)

Eastell R, Reid DM, Compston J, Cooper C, Fogelman I, Francis RM, Hosking DJ, Purdie DW, Ralston SH, Reeve J, et al. 1998 A UK Consensus Group on management of glucocorticoid-induced osteoporosis: an update. Journal of Internal Medicine 244 271-292. (https://doi.org/10.1046/j.1365-2796.1998.00408.x)

Eberwine J 1999 Glucocorticoid and mineralocorticoid receptors as transcription factors. In Basic Neurochemistry: Molecular, Cellular and Medical Aspects, 6th edition. Eds G Siegel, BA Granoff \& RW Albers. Philidelphia, PA, USA: Lippincott-Raven.

El-Hajj Fuleihan G, Muwakkit S, Arabi A, Daouk LE, Ghalayini T, Chaiban J \& Abboud M 2012 Predictors of bone loss in childhood hematologic malignancies: a prospective study. Osteoporosis International 23 665-674. (https://doi.org/10.1007/s00198-011$1605-2)$

Escolar DM, Hache LP, Clemens PR, Cnaan A, McDonald CM, Viswanathan V, Kornberg AJ, Bertorini TE, Nevo Y, Lotze T, et al. 2011 Randomized, blinded trial of weekend vs daily prednisone in Duchenne muscular dystrophy. Neurology 77 444-452. (https://doi. org/10.1212/WNL.0b013e318227b164)

Espina B, Liang M, Russell RGG \& Hulley PA 2008 Regulation of bim in glucocorticoid-mediated osteoblast apoptosis. Journal of Cellular Physiology 215 488-496. (https://doi.org/10.1002/jcp.21335)

Farquharson C \& Jefferies D 2000 Chondrocytes and longitudinal bone growth: the development of tibial dyschondroplasia. Poultry Science 79 994-1004. (https://doi.org/10.1093/ps/79.7.994)

Farquharson C \& Loveridge N 1990 Cell proliferation within the growth plate of long bones assessed by bromodeoxyuridine uptake and its relationship to glucose 6-phosphate dehydrogenase activity. Bone and Mineral 10 121-130. (https://doi.org/10.1016/01696009(90)90087-V)

Fumoto T, Ishii K, Ito M, Berger S, Schütz G \& Ikeda K 2014 Mineralocorticoid receptor function in bone metabolism and its role in glucocorticoid-induced osteopenia. Biochemical and Biophysical Research Communications 447 407-412. (https://doi.org/10.1016/j. bbrc.2014.03.149)
Glendenning P 2011 Markers of bone turnover for the prediction of fracture risk and monitoring of osteoporosis treatment: a need for international reference standards. Osteoporosis International 22 391-420.

Grahnemo L, Jochems C, Andersson A, Engdahl C, Ohlsson C, Islander U \& Carlsten H 2015 Possible role of lymphocytes in glucocorticoidinduced increase in trabecular bone mineral density. Journal of Endocrinology 224 97-108. (https://doi.org/10.1530/JOE-14-0508)

Harada SI, Balena R, Rodan GA \& Rodan SB 1995 The role of prostaglandins in bone formation. Connective Tissue Research $\mathbf{3 1}$ 279-282. (https://doi.org/10.3109/03008209509010823)

Hartmann K, Koenen M, Schauer S, Wittig-Blaich S, Ahmad M, Baschant U \& Tuckermann JP 2016 Molecular actions of glucocorticoids in cartilage and bone during health, disease, and steroid therapy. Physiological Reviews 96 409-447. (https://doi. org/10.1152/physrev.00011.2015)

Henneicke H, Herrmann M, Kalak R, Brennan-Speranza TC, Heinevetter U, Bertollo N, Day RE, Huscher D, Buttgereit F, Dunstan CR, et al. 2011 Corticosterone selectively targets endocortical surfaces by an osteoblast-dependent mechanism. Bone 49 733-742. (https://doi.org/10.1016/j.bone.2011.06.013)

Henneicke H, Gasparini SJ, Brennan-Speranza TC, Zhou H \& Seibel MJ 2014 Glucocorticoids and bone: local effects and systemic implications. Trends in Endocrinology and Metabolism 25 197-211. (https://doi.org/10.1016/j.tem.2013.12.006)

Herrmann M, Henneicke H, Street J, Modzelewski J, Kalak R, Buttgereit F, Dunstan CR, Zhou H \& Seibel MJ 2009 The challenge of continuous exogenous glucocorticoid administration in mice. Steroids $\mathbf{7 4}$ 245-249. (https://doi.org/10.1016/j.steroids.2008.11.009)

Hofbauer LC, Zeitz U, Schoppet M, Skalicky M, Schuler C, Stolina M, Kostenuik PJ, Erben RG, Schüler C, Stolina M, et al. 2009 Prevention of glucocorticoid-induced bone loss in mice by inhibition of RANKL. Arthritis and Rheumatism 60 1427-1437. (https://doi.org/10.1002/ art.24445)

Hughes PC \& Tanner JM 1970 A longitudinal study of the growth of the black-hooded rat: methods of measurement and rates of growth for skull, limbs, pelvis, nose-rump and tail lengths. Journal of Anatomy 106 349-370.

Huizenga NATM, Koper JW, de Lange P, Pols HAP, Stolk RP, Burger H, Grobbee DE, Brinkmann AO, de Jong FH \& Lamberts SWJ 1998 A polymorphism in the glucocorticoid receptor gene may be associated with an increased sensitivity to glucocorticoids in vivo. Journal of Clinical Endocrinology and Metabolism 83 144-151. (https://doi. org/10.1210/jcem.83.1.4490)

Hunziker EB \& Schenk RK 1989 Physiological mechanisms adopted by chondrocytes in regulating longitudinal bone growth in rats. Journal of Physiology 414 55-71. (https://doi.org/10.1113/jphysiol.1989. sp017676)

Iida-Klein A, Lu SS, Yokoyama K, Dempster DW, Nieves JW \& Lindsay R 2003 Precision, accuracy, and reproducibility of dual X-ray absorptiometry measurements in mice in vivo. Journal of Clinical Densitometry 6 25-33.

Interlichia JP, Williams NG, Rodgers BDBD, Greenspan FS, Li CH, Simpson ME, Evans HM, Smeets T, van Buul-Offers S, Rodgers BDBD, et al. 2010 A rapid, valid and inexpensive assay for measuring epiphyseal plates in mouse tibia. Growth Hormone and IGF Research 20 171-173. (https://doi.org/10.1016/j.ghir.2009.10.004)

Iwamoto J, Matsumoto H, Takeda T, Sato Y, Liu X \& Yeh JK 2008 Effects of vitamin $\mathrm{K} 2$ and risedronate on bone formation and resorption, osteocyte lacunar system, and porosity in the cortical bone of glucocorticoid-treated rats. Calcified Tissue International 83 121-128. (https://doi.org/10.1007/s00223-008-9146-1)

Jansson J, Ekberg S, Isaksson J, Mode A \& Gustafsson J 1985 Imprinting of growth hormone secretion, body growth, and hepatic steroid metabolism by neonatal testosterone. Endocrinology 117 1881-1889. (https://doi.org/10.1210/endo-117-5-1881) 
Javaid MKK \& Cooper C 2002 Prenatal and childhood influences on osteoporosis. Best Practice and Research 16 349-367. (https://doi. org/10.1053/beem.2002.0199)

Jepsen KJ, Silva MJ, Vashishth D, Guo XE \& van der Meulen MC 2015 Establishing biomechanical mechanisms in mouse models: practical guidelines for systematically evaluating phenotypic changes in the diaphyses of long bones. Journal of Bone and Mineral Research 30 951-966. (https://doi.org/10.1002/jbmr.2539)

Jia D, O'Brien CA, Stewart SA, Manolagas SC \& Weinstein RS 2006 Glucocorticoids act directly on osteoclasts to increase their life span and reduce bone density. Endocrinology 147 5592-5599. (https://doi. org/10.1210/en.2006-0459)

Jia J, Yao W, Guan M, Dai W, Shahnazari M, Kar R, Bonewald L, Jiang JX \& Lane NE 2011 Glucocorticoid dose determines osteocyte cell fate. FASEB Journal 25 3366-3376. (https://doi.org/10.1096/fj.11-182519)

Jiang Y, Gou H, Wang S, Zhu J, Tian S \& Yu L 2016 Effect of pulsed electromagnetic field on bone formation and lipid metabolism of glucocorticoid-induced osteoporosis rats through canonical Wnt signaling pathway. Evidence-Based Complementary and Alternative Medicine 2016 1-13. (https://doi.org/10.1155/2016/4927035)

Jilka RL 2013 The relevance of mouse models for investigating age-related bone loss in humans. Journals of Gerontology 68 1209-1217. (https://doi.org/10.1093/gerona/glt046)

Jones JI \& Clemmons DR 1995 Insulin-like growth factors and their binding proteins: biological actions. Endocrine Reviews 16 3-34. (https://doi.org/10.1210/edrv-16-1-3)

Jux C, Leiber K, Hügel U, Blum W, Ohlsson C, Klaus G \& Mehls O 1998 Dexamethasone impairs growth hormone $(\mathrm{GH})$-stimulated growth by suppression of local insulin-like growth factor (IGF)-I production and expression of GH- and IGF-I-receptor in cultured rat chondrocytes. Endocrinology 139 3296-3305. (https://doi.org/10.1210/ endo.139.7.6099)

Kanis JA, Johansson H, Oden A, Johnell O, de Laet C, Melton LJ, Tenenhouse A, Reeve J, Silman AJ, Pols HA, et al. 2004 A meta-analysis of prior corticosteroid use and fracture risk. Journal of Bone and Mineral Research 19 893-899. (https://doi.org/10.1359/JBMR.040134)

Karsenty G \& Wagner EF 2002 Reaching a genetic and molecular understanding of skeletal development. Developmental Cell 2 389-406. (https://doi.org/10.1016/S1534-5807(02)00157-0)

Kemer S, Karademir F, Aydemir G, Kucukodaci Z, Pirgon O, Genc FA \& Aydinoz S 2015 Effects of inhaled corticosteroids on the growth plates of infant rats. Fetal and Pediatric Pathology 34 223-232. (https://doi. org/10.3109/15513815.2015.1042606)

Kilborn SH, Trudel G \& Uhthoff H 2002 Review of growth plate closure compared with age at sexual maturity and lifespan in laboratory animals. Contemporary Topics in Laboratory Animal Science 41 21-26.

Kim H-J, Zhao H, Kitaura H, Bhattacharyya S, Brewer JA, Muglia LJ, Ross FP \& Teitelbaum SL 2006 Glucocorticoids suppress bone formation via the osteoclast. Journal of Clinical Investigation 116 2152-2160. (https://doi.org/10.1172/JCI28084)

Kim H-J, Zhao H, Kitura H, Bhattacharyya S, Brewer JA, Muglia LJ, Patrick Ross F \& Teitelbaum SL 2007 Glucocorticoids and the Osteoclast. Annals of the New York Academy of Sciences 1116 335-339. (https://doi. org/10.1196/annals.1402.057)

King CS, Weir EC, Gundberg CW, Fox J \& Insogna KL 1996 effects of continuous glucocorticoid infusion on bone metabolism in the rat. Calcified Tissue International 59 184-191. (https://doi.org/10.1007/ s002239900107)

Klaus G, Jux C, Fernandez P, Rodriguez J, Himmele R \& Mehls O 2000 Suppression of growth plate chondrocyte proliferation by corticosteroids. Pediatric Nephrology 14 612-615. (https://doi. org/10.1007/s004670000344)

Klinck RJ, Campbell GM \& Boyd SK 2008 Radiation effects on bone architecture in mice and rats resulting from in vivo micro-computed tomography scanning. Medical Engineering and Physics 30 888-895. (https://doi.org/10.1016/j.medengphy.2007.11.004)
Kokoroghiannis C, Charopoulos I, Lyritis G, Raptou P, Karachalios T \& Papaioannou N 2009 Correlation of pQCT bone strength index with mechanical testing in distraction osteogenesis. Bone 45 512-516. (https://doi.org/10.1016/j.bone.2009.05.021)

Kugelberg M, Shafiei K, Ohlsson C, Sävendahl L \& Zetterström C 2005 Glucocorticoid eye drops inhibit growth in the newborn rabbit. Acta Paediatrica 94 1096-1101. (https://doi. org/10.1080/08035250510028731)

Kyrylkova K, Kyryachenko S, Leid M \& Kioussi C 2012 Detection of apoptosis by TUNEL assay. In Odontogenesis: Methods in Molecular Biology (Methods and Protocols), 887 41-47. Ed. C Kioussi. Clifton, NJ, USA: Humana Press. (https://doi.org/10.1007/978-1-61779-8603_5)

Lane NE 2005 New observations on bone fragility with glucocorticoid treatment. Results from an in vivo animal model. Journal of Musculoskeletal and Neuronal Interactions 5 331-332.

Lane NE, Yao W, Balooch M, Nalla RK, Balooch G, Habelitz S, Kinney JH \& Bonewald LF 2006 Glucocorticoid-treated mice have localized changes in trabecular bone material properties and osteocyte lacunar size that are not observed in placebo-treated or estrogen-deficient mice. Journal of Bone and Mineral Research 21 466-476. (https://doi. org/10.1359/JBMR.051103)

Laperre K, Depypere M, van Gastel N, Torrekens S, Moermans K, Bogaerts R, Maes F \& Carmeliet G 2011 Development of micro-CT protocols for in vivo follow-up of mouse bone architecture without major radiation side effects. Bone 49 613-622. (https://doi. org/10.1016/j.bone.2011.06.031)

Lelovas PP, Xanthos TT, Thoma SE, Lyritis GP \& Dontas IA 2008 The laboratory rat as an animal model for osteoporosis research. Comparative Medicine 58 424-430.

Li X, Zhou Z, Zhang Y \& Yang H 2016 IL-6 contributes to the defective osteogenesis of bone marrow stromal cells from the vertebral body of the glucocorticoid-induced osteoporotic mouse. PLOS ONE 11 e0154677. (https://doi.org/10.1371/journal. pone.0154677)

Lin S, Huang J, Liang ZZ, Liu Y, Liu G, Li N, Wang K, Liyi ZZZZZ, Wu T, Qin L, et al. 2014 Glucocorticoid-Induced Osteoporosis in Growing Rats. Calcified Tissue International 95 362-373. (https://doi. org/10.1007/s00223-014-9899-7)

Lin T, Liu J, Yang S, Liu X, Feng X \& Fu D 2016 Relation between the development of osteoporosis and osteonecrosis following glucocorticoid in a rabbit model. Indian Journal of Orthopaedics 50 406. (https://doi.org/10.4103/0019-5413.185606)

Liu F, Woitge HW, Braut A, Kronenberg MS, Lichtler AC, Mina M \& Kream BE 2004 Expression and activity of osteoblast-targeted Cre recombinase transgenes in murine skeletal tissues. International Journal of Developmental Biology 48 645-653. (https://doi.org/10.1387/ ijdb.041816fl)

Mackie EJ, Tatarczuch L \& Mirams M 2011 The skeleton: a multifunctional complex organ. The growth plate chondrocyte and endochondral ossification. Journal of Endocrinology 211 109-121. (https://doi.org/10.1530/JOE-11-0048)

Mårtensson K, Chrysis D \& Sävendahl L 2004 Interleukin-1 $\beta$ and TNF- $\alpha$ act in synergy to inhibit longitudinal growth in fetal rat metatarsal bones. Journal of Bone and Mineral Research 19 1805-1812. (https://doi. org/10.1359/JBMR.040805)

Matthews E, Brassington R, Kuntzer T, Jichi F \& Manzur AY 2016 Corticosteroids for the treatment of Duchenne muscular dystrophy. In Cochrane Database of Systematic Reviews, CD003725. Ed E Matthews. Chichester, UK: John Wiley \& Sons, Ltd. (https://doi. org/10.1002/14651858.CD003725.pub4)

Mazziotti G \& Giustina A 2013 Glucocorticoids and the regulation of growth hormone secretion. Nature Reviews Endocrinology 9 265-276. (https://doi.org/10.1038/nrendo.2013.5)

McDonald DG, Kinali M, Gallagher AC, Mercuri E, Muntoni F, Roper H, Jardine P, Jones DH \& Pike MG 2002 Fracture prevalence in Duchenne 
muscular dystrophy. Developmental Medicine and Child Neurology 44 695-698. (https://doi.org/10.1111/j.1469-8749.2002.tb00272.x)

McLaughlin F, Mackintosh J, Hayes BP, McLaren A, Uings IJ, Salmon P, Humphreys J, Meldrum E \& Farrow SN 2002 Glucocorticoidinduced osteopenia in the mouse as assessed by histomorphometry, microcomputed tomography, and biochemical markers. Bone 30 924-930. (https://doi.org/10.1016/S8756-3282(02)00737-8)

Meikle AW \& Tyler FH 1977 Potency and duration of action of glucocorticoids. Effects of hydrocortisone, prednisone and dexamethasone on human pituitary-adrenal function. American Journal of Medicine 63 200-207. (https://doi.org/10.1016/00029343(77)90233-9)

Melin AD, Bergmann PJ \& Russell AP 2005 Mammalian postnatal growth estimates: the influence of weaning on the choice of a comparative metric. Journal of Mammalogy 86 1042-1049. (https://doi. org/10.1644/1545-1542(2005)86[1042:MPGETI]2.0.CO;2)

Mosier HD \& Jansons RA 1989 Rats stunted by high-dose glucocorticoid treatment are capable of undergoing catch-up growth after fasting. Pediatric Research 25 373-376. (https://doi.org/10.1203/00006450198904000-00013)

Mushtaq T \& Ahmed SF 2002 The impact of corticosteroids on growth and bone health. Archives of Disease in Childhood 87 93-96. (https://doi.org/10.1136/ADC.87.2.93)

Mushtaq T, Bijman P, Ahmed SF \& Farquharson C 2004 Insulin-like growth factor-I augments chondrocyte hypertrophy and reverses glucocorticoid-mediated growth retardation in fetal mice metatarsal cultures. Endocrinology 145 2478-2486. (https://doi.org/10.1210/ en.2003-1435)

Nakashima T, Hayashi M, Fukunaga T, Kurata K, Oh-hora M, Feng JQ Bonewald LF, Kodama T, Wutz A, Wagner EF, et al. 2011 Evidence for osteocyte regulation of bone homeostasis through RANKL expression. Nature Medicine 17 1231-1234. (https://doi.org/10.1038/nm.2452)

Ogoshi T, Hagino H, Fukata S, Tanishima S, Okano T \& Teshima R 2008 Influence of glucocorticoid on bone in 3-, 6-, and 12-month-old rats as determined by bone mass and histomorphometry. Modern Rheumatology 18 552-561. (https://doi.org/10.1007/s10165-008-0096-2)

Ohnaka K, Tanabe M, Kawate H, Nawata H \& Takayanagi R 2005 Glucocorticoid suppresses the canonical Wnt signal in cultured human osteoblasts. Biochemical and Biophysical Research Communications 329 177-181. (https://doi.org/10.1016/j. bbrc.2005.01.117)

Olgaard K, Storm T, van Wowern N, Daugaard H, Egfjord M, Lewin E \& Brandi L 1992 Glucocorticoid-induced osteoporosis in the lumbar spine, forearm, and mandible of nephrotic patients: a double-blind study on the high-dose, long-term effects of prednisone versus deflazacort. Calcified Tissue International 50 490-497. (https://doi. org/10.1007/BF00582160)

Ortoft G, Oxlund H, Jørgensen PH \& Andreassen TT 1992 Glucocorticoid treatment or food deprivation counteract the stimulating effect of growth hormone on rat cortical bone strength. Acta Paediatrica $\mathbf{8 1}$ 912-917. (https://doi.org/10.1111/j.1651-2227.1992.tb12134.x)

Ortoft G, Oxlund H \& Andreassen TT 1998a Administration of a glucocorticoid with depot effect counteracts the stimulating effect of growth hormone on cancellous and cortical bone of the vertebral body in rats. Calcified Tissue International 63 14-21.

Ortoft G, Grønbaek H \& Oxlund H $1998 b$ Growth hormone administration can improve growth in glucocorticoid-injected rats without affecting the lymphocytopenic effect of the glucocorticoid. Growth Hormone and IGF Research 8 251-264.

Owen HC, Miner JN, Ahmed SF \& Farquharson C 2007 The growth plate sparing effects of the selective glucocorticoid receptor modulator, AL-438. Molecular and Cellular Endocrinology 264 164-170. (https://doi.org/10.1016/j.mce.2006.11.006)

Owen HC, Ahmed SF \& Farquharson C 2009 Chondrocyte p21(WAF1/ CIP1) expression is increased by dexamethasone but does not contribute to dexamethasone-induced growth retardation in vivo. Calcified Tissue International 85 326-334. (https://doi.org/10.1007/ s00223-009-9276-0)

Pappa H, Thayu M, Sylvester F, Leonard M, Zemel B \& Gordon C 2011 Skeletal health of children and adolescents with inflammatory bowel disease. Journal of Pediatric Gastroenterology and Nutrition 53 11-25. (https://doi.org/10.1097/MPG.0b013e31821988a3)

Pereira RC, Delany AM \& Canalis E 2002 Effects of cortisol and bone morphogenetic protein-2 on stromal cell differentiation: correlation with CCAAT-enhancer binding protein expression. Bone 30 685-691. (https://doi.org/10.1016/S8756-3282(02)00687-7)

Plotkin LII, Bivi N \& Bellido T 2011 A bisphosphonate that does not affect osteoclasts prevents osteoblast and osteocyte apoptosis and the loss of bone strength induced by glucocorticoids in mice. Bone $\mathbf{4 9}$ 122-127. (https://doi.org/10.1016/j.bone.2010.08.011)

Pogoda P, Priemel M, Schilling AF, Gebauer M, Catalfi-Lehnen P, Barvencik F, Beil T, Miinch C, Rupprecht M, Miildner C, et al. 2005 Mouse models in skeletal physiology and osteoporosis: experiences and data on 14839 cases from the Hamburg Mouse Archives. Journal of Bone and Mineral Metabolism 23 97-102. (https://doi.org/10.1007/ BF03026332)

Postnov A, Schutter T, Sijbers J, Karperien M \& Clerck N 2009 Glucocorticoid-induced osteoporosis in growing mice is not prevented by simultaneous intermittent PTH treatment. Calcified Tissue International 85 530-537. (https://doi.org/10.1007/s00223-0099301-3)

Price WA, Stiles AD, Moats-Staats BM \& D'Ercole AJ 1992 Gene expression of insulin-like growth factors (IGFs), the type 1 IGF receptor, and IGF-binding proteins in dexamethasone-induced fetal growth retardation. Endocrinology 130 1424-1432. (https://doi.org/10.1210/ endo.130.3.1371449)

Rauch A, Seitz S, Baschant U, Schilling AF, Illing A, Stride B, Kirilov M, Mandic V, Takacz A, Schmidt-Ullrich R, et al. 2010 Glucocorticoids suppress bone formation by attenuating osteoblast differentiation via the monomeric glucocorticoid receptor. Cell Metabolism 11 517-531. (https://doi.org/10.1016/j.cmet.2010.05.005)

Reid IR 1997 Glucocorticoid osteoporosis - mechanisms and management. European Journal of Endocrinology 137 209-217. (https://doi.org/10.1530/eje.0.1370209)

Reinwald S \& Burr D 2008 Review of nonprimate, large animal models for osteoporosis research. Journal of Bone and Mineral Research 23 1353-1368. (https://doi.org/10.1359/jbmr.080516)

Ricotti V, Ridout DA, Scott E, Quinlivan R, Robb SA, Manzur AY \& Muntoni F 2013 Long-term benefits and adverse effects of intermittent versus daily glucocorticoids in boys with Duchenne muscular dystrophy. Journal of Neurology, Neurosurgery, and Psychiatry 84 698-705. (https://doi.org/10.1136/jnnp-2012-303902)

Rooman R, Koster G, Bloemen R, Gresnigt R \& van Buul-Offers SC 1999 The effect of dexamethasone on body and organ growth of normal and IGF-II-transgenic mice. Journal of Endocrinology 163 543-552. (https://doi.org/10.1677/joe.0.1630543)

Sato AY, Cregor M, Delgado-Calle J, Condon KW, Allen MR, Peacock M, Plotkin LI \& Bellido T 2016 Protection from glucocorticoid-induced osteoporosis by anti-catabolic signaling in the absence of SOST/ sclerostin. Journal of Bone and Mineral Research 31 1791-1802. (https://doi.org/10.1002/jbmr.2869)

Scholz-Ahrens KE, Delling G, Stampa B, Helfenstein A, Hahne H-J, Acil Y, Timm W, Barkmann R, Hassenpflug J, Schrezenmeir J, et al. 2007 Glucocorticosteroid-induced osteoporosis in adult primiparous Gottingen miniature pigs: effects on bone mineral and mineral metabolism. AJP: Endocrinology and Metabolism 293 E385-E395. (https://doi.org/10.1152/ajpendo.00627.2006)

Silvestrini G, Ballanti P, Patacchioli FR, Mocetti P, Di Grezia R, Wedard BM, Angelucci L \& Bonucci E 2000 Evaluation of apoptosis and the glucocorticoid receptor in the cartilage growth plate and
(C) 2018 Society for Endocrinology Published by Bioscientifica Ltd. Printed in Great Britain 
metaphyseal bone cells of rats after high-dose treatment with corticosterone. Bone 26 33-42. (https://doi.org/10.1016/S87563282(99)00245-8)

Simon D, Fernando C, Czernichow P \& Prieur A-M 2002 Linear growth and final height in patients with systemic juvenile idiopathic arthritis treated with longterm glucocorticoids. Journal of Rheumatology 29 1296-1300.

Siu WS, Qin L \& Leung KS 2003 pQCT bone strength index may serve as a better predictor than bone mineral density for long bone breaking strength. Journal of Bone and Mineral Metabolism 21 316-322. (https://doi.org/10.1007/s00774-003-0427-5)

Śliwa E, Kowalik S, Tatara MR, Majcher P, Krupski W \& Studziński T 2005 Effects of dexamethasone on physical properties and mineral density of long bones in piglets. Bulletin of the Veterinary Institute in Pulawy 49 97-100.

Smink JJ, Koster JG, Gresnigt MG, Rooman R, Koedam JA \& Van BuulOffers SC 2002 IGF and IGF-binding protein expression in the growth plate of normal, dexamethasone-treated and human IGF-II transgenic mice. Journal of Endocrinology 175 143-153. (https://doi.org/10.1677/ joe.0.1750143)

Smink JJ, Gresnigt MG, Hamers N, Koedam JA, Berger R \& Van BuulOffers SC 2003a Short-term glucocorticoid treatment of prepubertal mice decreases growth and IGF-I expression in the growth plate. Journal of Endocrinology 177 381-388. (https://doi.org/10.1677/ joe.0.1770381)

Smink JJ, Buchholz IM, Hamers N, van Tilburg CM, Christis C, Sakkers RJB, de Meer K, van Buul-Offers SC \& Koedam JA 2003b Short-term glucocorticoid treatment of piglets causes changes in growth plate morphology and angiogenesis. Osteoarthritis and Cartilage 11 864-871. (https://doi.org/10.1016/S10634584(03)00187-0)

Van Staa TP, Leufkens HGM, Abenhaim L, Zhang B \& Cooper C 2000 Use of oral corticosteroids and risk of fractures. Journal of Bone and Mineral Research 15 993-1000. (https://doi.org/10.1359/jbmr.2000.15.6.993)

Stewart PM 2007 The adrenal cortex. In Williams Textbook of Endocrinology, 11th edition. Eds H Kronenberg, S Melmed, K Polonsky \& PR Larsen. Philadelphia, PA, USA: Saunders Elsevier.

Sundahl N, Bridelance J, Libert C, De Bosscher K \& Beck IM 2015 Selective glucocorticoid receptor modulation: new directions with non-steroidal scaffolds. Pharmacology and Therapeutics 152 28-41. (https://doi.org/10.1016/j.pharmthera.2015.05.001)

Tamura Y, Kawao N, Yano M, Okada K, Okumoto K, Chiba Y, Matsuo O \& Kaji H 2015 Role of plasminogen activator inhibitor-1 in glucocorticoid-induced diabetes and osteopenia in mice. Diabetes 64 2194-2206. (https://doi.org/10.2337/db14-1192)

Tanaka H, Hirano F, Nomura Y, Miura T, Makino Y, Fukawa E \& Makino I 1994 Relative glucocorticoid potency revisited. Rheumatology International 14 9-12. (https://doi.org/10.1007/BF00302665)

Thiele S, Ziegler N, Tsourdi E, De Bosscher K, Tuckermann JP, Hofbauer LC \& Rauner M 2012 Selective glucocorticoid receptor modulation maintains bone mineral density in mice. Journal of Bone and Mineral Research 27 2242-2250. (https://doi.org/10.1002/jbmr.1688)

Thompson DD, Simmons HA, Pirie CM \& Ke HZ 1995 FDA Guidelines and animal models for osteoporosis. Bone 17 125S-133S.

Tulipano G, Taylor JE, Halem HA, Datta R, Dong JZ, Culler MD, Bianchi I, Cocchi D \& Giustina A 2007 Glucocorticoid inhibition of growth in rats: partial reversal with the full-length ghrelin analog BIM-28125. Pituitary 10 267-274. (https://doi.org/10.1007/s11102-007-0054-6)

Umlawska W \& Prusek-Dudkiewicz A 2010 Growth retardation and delayed puberty in children and adolescents with juvenile idiopathic arthritis. Archives of Medical Science 6 19-23. (https://doi.org/10.5114/ aoms.2010.13501)

Waarsing J, Day J, van der Linden J, Ederveen A, Spanjers C, De Clerck N, Sasov A, Verhaar JA \& Weinans H 2004 Detecting and tracking local changes in the tibiae of individual rats: a novel method to analyse longitudinal in vivo micro-CT data. Bone 34 163-169. (https://doi. org/10.1016/j.bone.2003.08.012)

Wallace AM, Tucker P, Williams DM, Hughes IA \& Ahmed SF 2003 Short-term effects of prednisolone and dexamethasone on circulating concentrations of leptin and sex hormone-binding globulin in children being treated for acute lymphoblastic leukaemia. Clinical Endocrinology 58 770-776. (https://doi.org/10.1046/j.1365-2265.2003.01790.x)

Wang F-S, Chung P-C, Lin C-L, Chen M-W, Ke H-J, Chang Y-H, Chen Y-S, Wu S-L \& Ko J-Y 2013 MicroRNA-29a protects against glucocorticoidinduced bone loss and fragility in rats by orchestrating bone acquisition and resorption. Arthritis and Rheumatism 65 1530-1540. (https://doi.org/10.1002/art.37948)

Ward WE, Donovan SM \& Atkinson SA 1998 Dexamethasone-induced abnormalities in growth and bone metabolism in piglets are partially attenuated by growth hormone with no synergistic effect of insulinlike growth factor-I. Pediatric Research 44 215-221. (https://doi. org/10.1203/00006450-199808000-00013)

Weber JC, VanHuss WD \& Mostosky U V 1968 Determination of bone length in vivo. Research Quarterly 39 223-224.

Weinstein RS \& Manolagas SC 2000 Apoptosis and osteoporosis. American Journal of Medicine 108 153-164. (https://doi.org/10.1016/S00029343(99)00420-9)

Weinstein RS, Jilka RL, Parfitt AM \& Manolagas SC 1998 Inhibition of osteoblastogenesis and promotion of apoptosis of osteoblasts and osteocytes by glucocorticoids potential mechanisms of their deleterious effects on bone. Journal of Clinical Investigation 102 274-282. (https://doi.org/10.1172/JCI2799)

Weinstein RS, O'Brien CA, Almeida M, Zhao H, Roberson PK, Jilka RL \& Manolagas SC 2011 Osteoprotegerin prevents glucocorticoid-induced osteocyte apoptosis in mice. Endocrinology 152 3323-3331. (https://doi.org/10.1210/en.2011-0170)

Weise M, De-Levi S, Barnes KM, Gafni RI, Abad V \& Baron J 2001 Effects of estrogen on growth plate senescence and epiphyseal fusion. PNAS 98 6871-6876. (https://doi.org/10.1073/pnas.121180498)

Wimalawansa SJ \& Simmons DJ 1998 Prevention of corticosteroidinduced bone loss with alendronate. Proceedings of the Society for Experimental Biology and Medicine 217 162-167. (https://doi. org/10.3181/00379727-217-44218)

Wong SC, Dobie R, Altowati MA, Werther GA, Farquharson C \& Ahmed SF 2016 Growth and the growth hormone-insulin like growth factor 1 axis in children with chronic inflammation: current evidence, gaps in knowledge, and future directions. Endocrine Reviews $\mathbf{3 7}$ 62-110. (https://doi.org/10.1210/er.2015-1026)

Xia X, Kar R, Gluhak-Heinrich J, Yao W, Lane NE, Bonewald LF, Biswas SK, Lo WK \& Jiang JX 2010 Glucocorticoid-induced autophagy in osteocytes. Journal of Bone and Mineral Research 25 2479-2488. (https://doi.org/10.1002/jbmr.160)

Xiong J, Onal M, Jilka RL, Weinstein RS, Manolagas SC \& O’Brien CA 2011 Matrix-embedded cells control osteoclast formation. Nature Medicine 17 1235-1241. (https://doi.org/10.1038/nm.2448)

Yao W, Cheng Z, Busse C, Pham A, Nakamura MC \& Lane NE 2008 Glucocorticoid excess in mice results in early activation of osteoclastogenesis and adipogenesis and prolonged suppression of osteogenesis: a longitudinal study of gene expression in bone tissue from glucocorticoid-treated mice. Arthritis and Rheumatism $\mathbf{5 8}$ 1674-1686. (https://doi.org/10.1002/art.23454)

Yao W, Dai W, Jiang L, Lay EY-A, Zhong Z, Ritchie RO, Li X, Ke H \& Lane NE 2016 Sclerostin-antibody treatment of glucocorticoidinduced osteoporosis maintained bone mass and strength. Osteoporosis International 27 283-294. (https://doi.org/10.1007/ s00198-015-3308-6)

Yokote Y, Kimura E, Kimura M \& Kozono Y 2008 Biomechanical analysis of combined treatment of high calcium and bisphosphonate in tibia of steroid-treated growing-phase rats. Dental Materials Journal 27 647-653. (https://doi.org/10.4012/dmj.27.647) 
Yongtao Z, Kunzheng W, Jingjing Z, Hu S, Jianqiang K, Ruiyu L \& Chunsheng W 2014 Glucocorticoids activate the local reninangiotensin system in bone: possible mechanism for glucocorticoidinduced osteoporosis. Endocrine 47 598-608. (https://doi.org/10.1007/ s12020-014-0196-z)

Zalavras C, Shah S, Birnbaum MJ \& Frenkel B 2003 Role of apoptosis in glucocorticoid-induced osteoporosis and osteonecrosis. Critical Reviews in Eukaryotic Gene Expression 13 221-235. (https://doi. org/10.1615/CritRevEukaryotGeneExpr.v13.i24.140)
Zaman F, Chrysis D, Huntjens K, Fadeel B, Sävendahl L, Mushtaq T, Ahmed S, Yeh T, Lin YY, Lin H, et al. 2012 Ablation of the pro-apoptotic protein bax protects mice from glucocorticoid-induced bone growth impairment. PLOS ONE 7 e33168. (https://doi.org/10.1371/journal. pone.0033168)

Zezulak KM \& Green H 1986 The generation of insulin-like growth factor-1 - sensitive cells by growth hormone action. Science 233 551-553. (https://doi.org/10.1126/science.3726546)

Received in final form 5 October 2017

Accepted 17 October 2017

Accepted preprint published online 17 October 2017 